1 乳用牛

(1) 飼養戸数 - 頭数

平成 30 年 2 月 1 日現在（以下「平成 30 年」という。）の全国の乳用牛の飼養戸数は 1 万 5,700 戸 で、廃業等により前年に比べ700戸 (4.3\%) 減少した。

飼養頭数は 132 万 8,000 頭で、前年に比べ 5,000 頭 $(0.4 \%)$ 増加した。飼養頭数の内訳をみると、 経産牛は84万7, 200頭で、前年に比べ4, 900頭 (0.6\%) 減少した。また、未経産牛は48万900頭で、 前年に比べ9, 900頭（2.1\%）増加した。

なお、1戸当たり飼養頭数は84.6頭で、前年に比べ3. 9頭増加した。

図 1 乳用牛の飼養戸数 ·頭数の推移
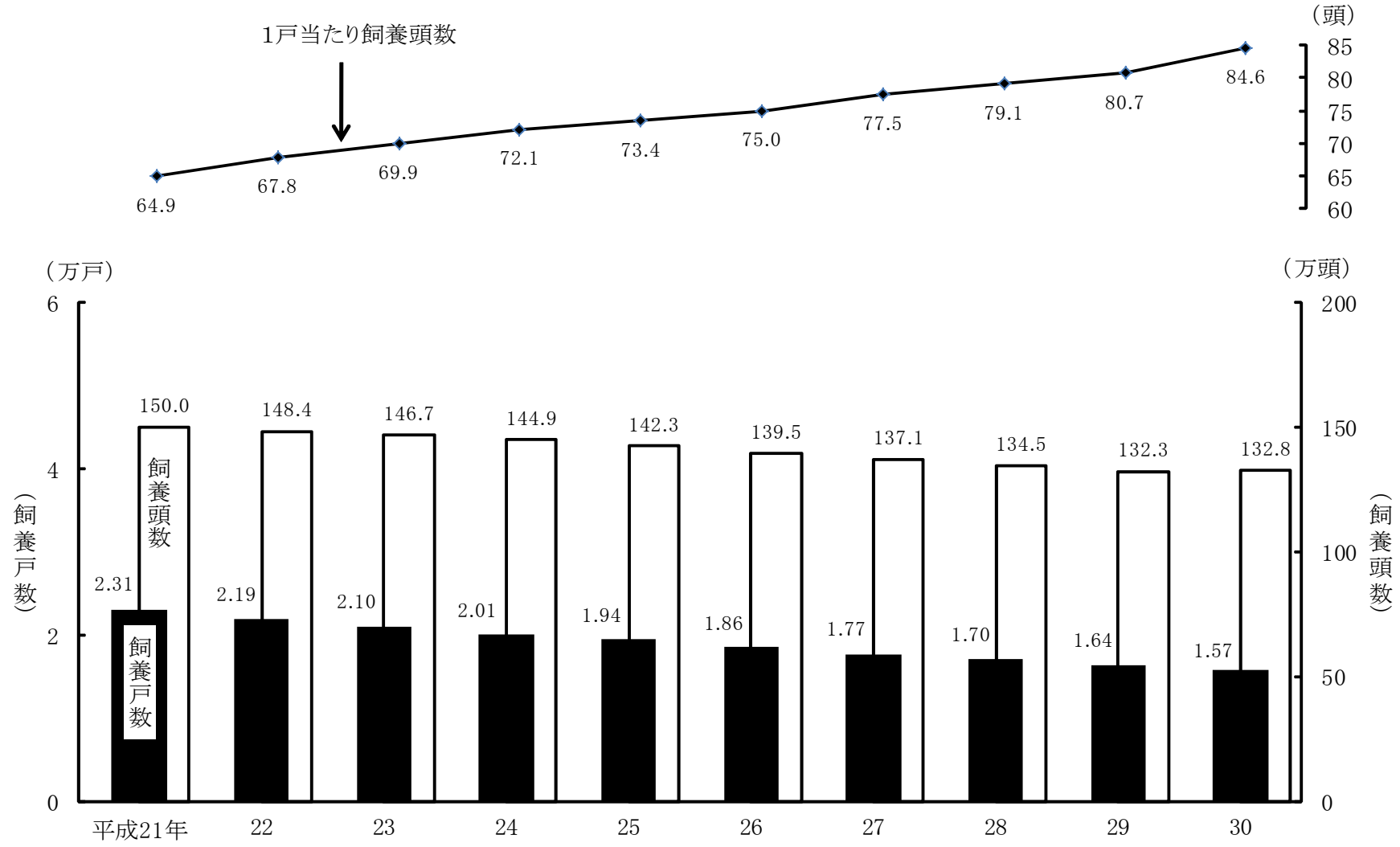

表 1 乳用牛の飼養戸数·飼養頭数

\begin{tabular}{|c|c|c|c|c|c|c|c|c|}
\hline \multirow{3}{*}{ 区 } & \multirow{3}{*}{ 分 } & \multirow{3}{*}{ 飼養戸数 } & \multicolumn{2}{|c|}{ 飼 } & \multicolumn{3}{|c|}{ 数 } & \multirow{3}{*}{$\begin{array}{c}1 \text { 戸当たり } \\
\text { 飼養頭数 }\end{array}$} \\
\hline & & & \multirow{2}{*}{ 計 } & 経 & 産 & 牛 & \multirow{2}{*}{ 未経産牛 } & \\
\hline & & & & 小 & 搾乳牛 & 乾乳牛 & & \\
\hline & & 户 & 千頭 & 千豆 & 千顽 & 千豆 & 千頭 & 頭 \\
\hline \multicolumn{9}{|l|}{ 実 } \\
\hline & 平成28年 & 17,000 & $1,345.0$ & 871.0 & 751.7 & 119.3 & 474.1 & 79.1 \\
\hline & 29 & 16,400 & $1,323.0$ & 852.1 & 735.2 & 116.9 & 471.0 & 80.7 \\
\hline & 30 & 15,700 & $1,328.0$ & 847.2 & 731.1 & 116.1 & 480.9 & 84.6 \\
\hline \multicolumn{9}{|l|}{ 対前年比 } \\
\hline 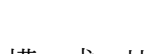 & $30 / 29(\%)$ & 95.7 & 100.4 & 99.4 & 99.4 & 99.3 & 102.1 & - \\
\hline & 平成 28 年（\%） & - & 100.0 & 64.8 & 55.9 & 8.9 & 35.2 & - \\
\hline & 29 & - & 100.0 & 64.4 & 55.6 & 8.8 & 35.6 & - \\
\hline & 30 & - & 100.0 & 63.8 & 55.1 & 8.7 & 36.2 & - \\
\hline
\end{tabular}

注 : 数值については、四捨五入のため合計と内訳の計が一致しないことがある（四捨五入の方法については11ページを参照。 以下表 22 まで同じ。）。 
（2） 全国農業地域別飼養戸数・頭数

全国農業地域別にみると、乳用牛の飼養戸数は、前年に比べ全ての地域で減少した。

飼養頭数は、前年に比べ北海道及び中国で増加したが、これ以外の地域では減少した。

なお、地域別の飼養頭数割合は、北海道が全国の約 6 割を占めている。

\section{図 2 乳用牛の全国農業地域別飼養戸数・頭数の前年比較}

一飼養戸数一

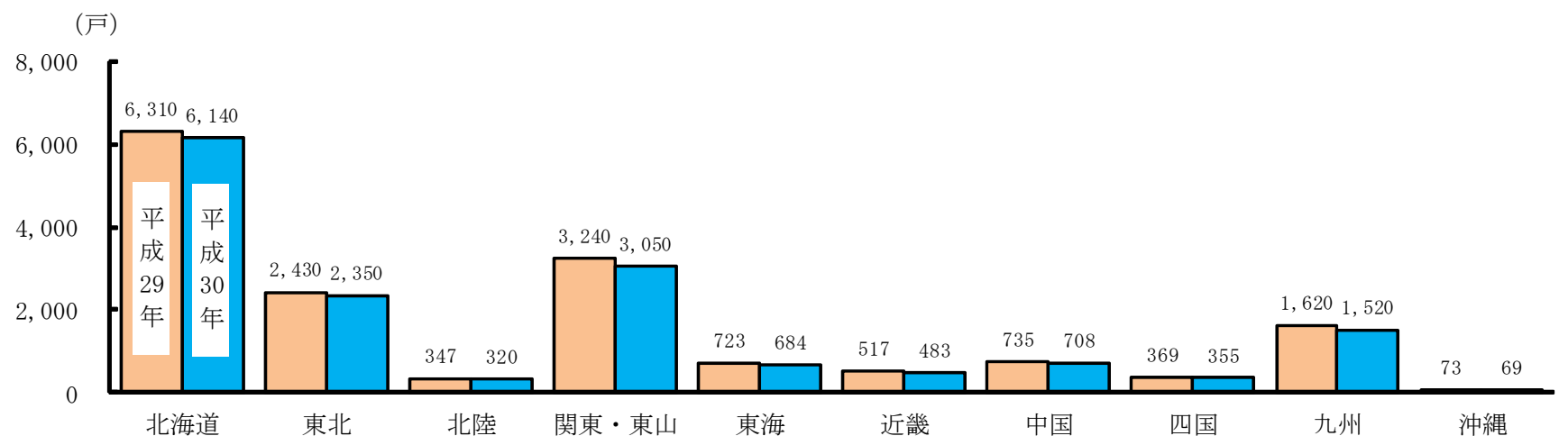

一飼養頭数一

(千頭)

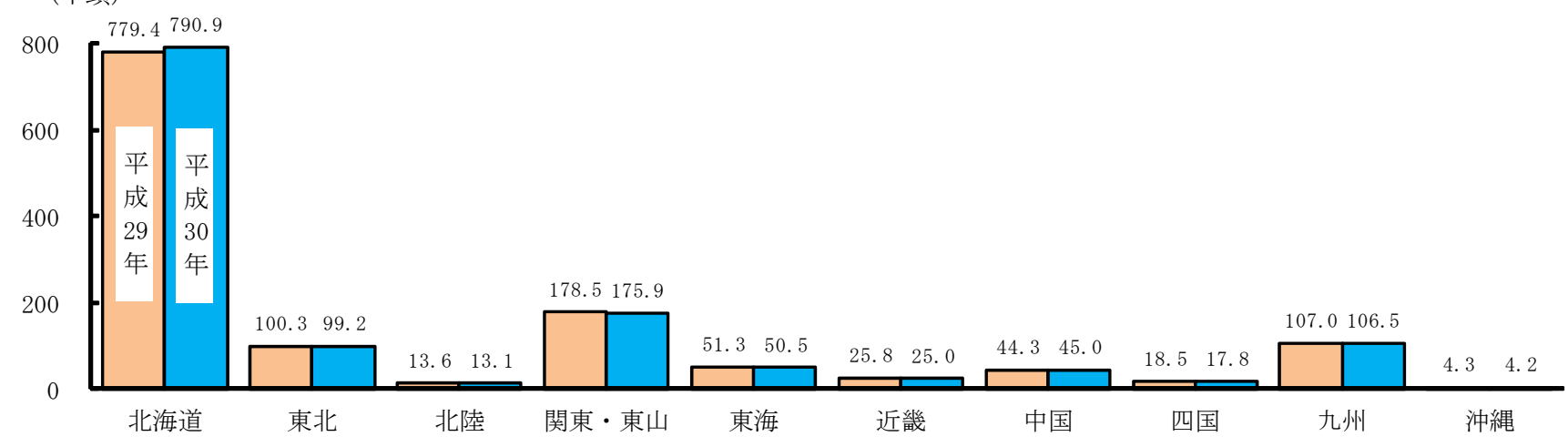

表 2 乳用牛の全国農業地域別飼養戸数・頭数

\begin{tabular}{|c|c|c|c|c|c|c|c|c|c|c|c|c|c|}
\hline 区 & 分 & 単位 & 全 国 & 北海道 & 東 北 & 北 陸 & $\begin{array}{l}\text { 関 東 } \\
\text { 東 山 }\end{array}$ & 東 海 & 近 畿 & 中 国 & 四 国 & 九 州 & 沖 縄 \\
\hline \multicolumn{14}{|c|}{ 飼 養 戸 数 } \\
\hline \multirow[t]{2}{*}{ 実 数 } & 数 平成 29年 & 戸 & 16,400 & 6,310 & 2,430 & 347 & 3,240 & 723 & 517 & 735 & 369 & 1,620 & 73 \\
\hline & 30 & $\prime \prime$ & 15,700 & 6,140 & 2,350 & 320 & 3,050 & 684 & 483 & 708 & 355 & 1,520 & 69 \\
\hline 対前年比 & 卣 $\quad 30 / 29$ & $\%$ & 95.7 & 97.3 & 96.7 & 92.2 & 94.1 & 94.6 & 93.4 & 96.3 & 96.2 & 93.8 & 94.5 \\
\hline \multirow[t]{2}{*}{ 全国割合 } & 今 平成 29 年 & $"$ & 100.0 & 38.5 & 14.8 & 2.1 & 19. 8 & 4.4 & 3.2 & 4.5 & 2.3 & 9.9 & 0.4 \\
\hline & 30 & $\prime \prime$ & 100.0 & 39.1 & 15.0 & 2. 0 & 19.4 & 4. 4 & 3.1 & 4. 5 & 2. 3 & 9.7 & 0.4 \\
\hline \multirow{3}{*}{$\begin{array}{c}\text { 飼 養 頭 数 } \\
\text { 実 }\end{array}$} & & & & & & & & & & & & & \\
\hline & 较平成 29 年 & 千頭 & $1,323.0$ & 779.4 & 100.3 & 13.6 & 178.5 & 51.3 & 25.8 & 44.3 & 18.5 & 107.0 & 4. 3 \\
\hline & 30 & $\prime \prime$ & $1,328.0$ & 790.9 & 99.2 & 13. 1 & 175.9 & 50.5 & 25.0 & 45.0 & 17. 8 & 106.5 & 4. 2 \\
\hline 対前年比 & $30 / 29$ & $\%$ & 100.4 & 101.5 & 98.9 & 96.3 & 98.5 & 98.4 & 96.9 & 101.6 & 96.2 & 99.5 & 97.2 \\
\hline \multirow[t]{2}{*}{ 全国割合 } & 平成 29 年 & " & 100.0 & 58.9 & 7.6 & 1.0 & 13.5 & 3.9 & 2.0 & 3.3 & 1.4 & 8.1 & 0.3 \\
\hline & 30 & "I & 100.0 & 59.6 & 7. 5 & 1.0 & 13. 2 & 3.8 & 1.9 & 3.4 & 1. 3 & 8. 0 & 0.3 \\
\hline
\end{tabular}

注：沖縄の飼養頭数の対前年比は、小数第 2 位までの実数をもとに算出している。 
（3） 成畜（満 2 歳以上の牛）飼養頭数規模別飼養戸数・頭数

乳用牛の成畜（満 2 歳以上の牛）飼養頭数規模別（学校、試験場等の非営利的な飼養者を含 まない。以下 $(4)$ 及び(5)において同じ。）にみると、飼養戸数及び飼養頭数は、ともに前年に比 ベ80～99頭及び100頭以上の階層で増加したが、これ以外の階層では減少した。

なお、成畜飼養頭数規模別の飼養頭数割合は、100頭以上の階層が約 4 割を占めている。

図 3 乳用牛の成畜飼養頭数規模別飼養戸数・頭数の前年比較

一飼養戸数一

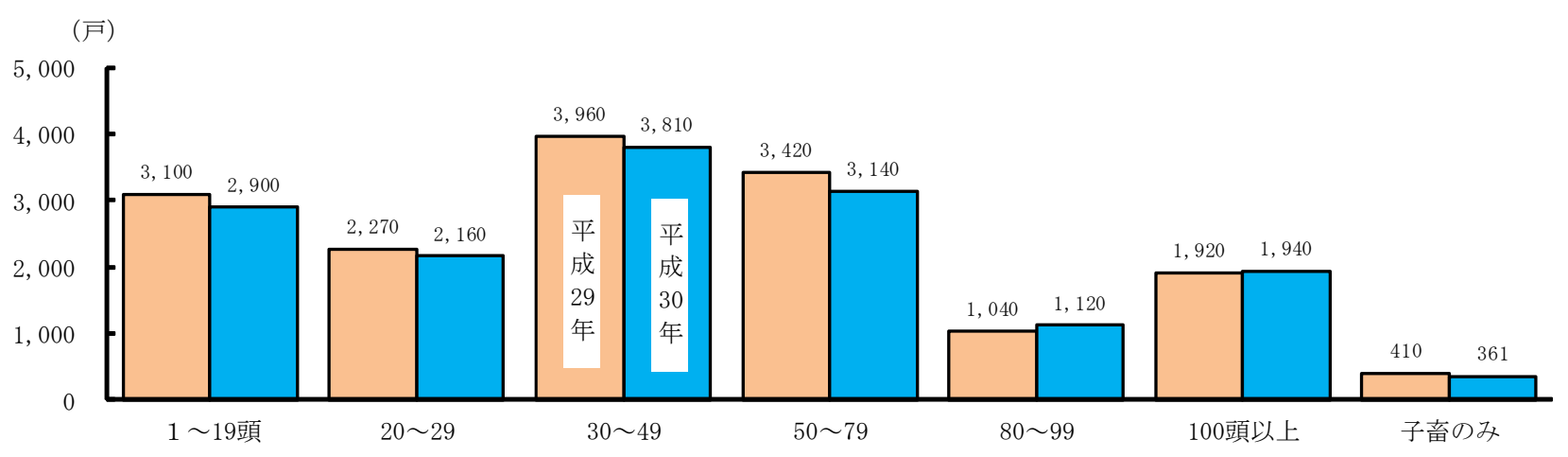

一飼養頭数一

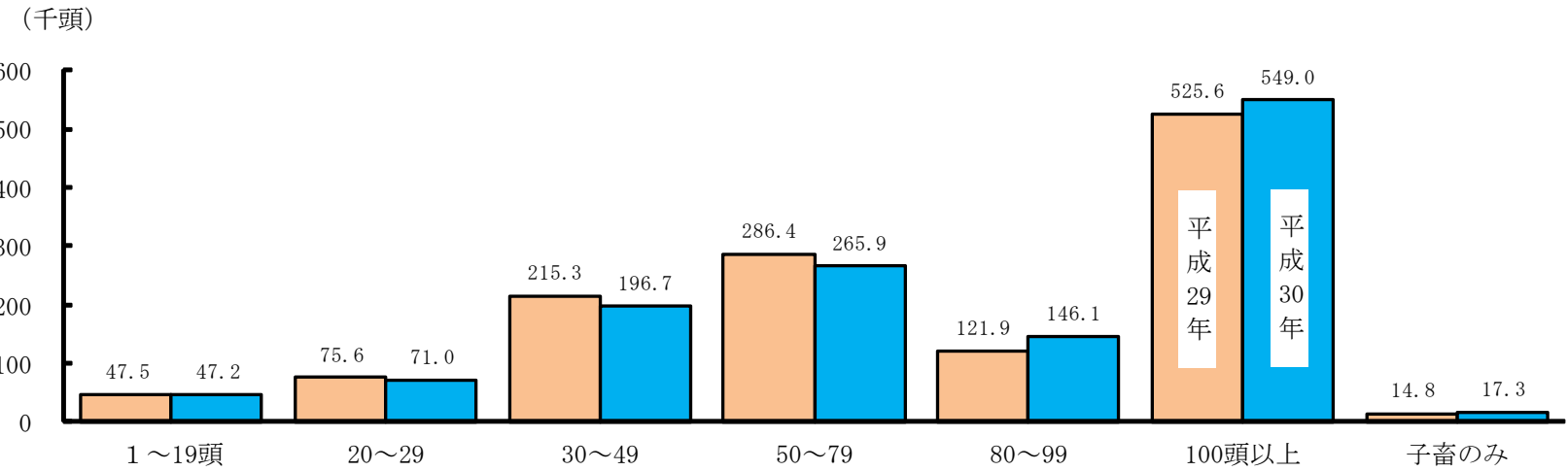

表 3 乳用牛の成畜飼養頭数規模別飼養戸数・頭数

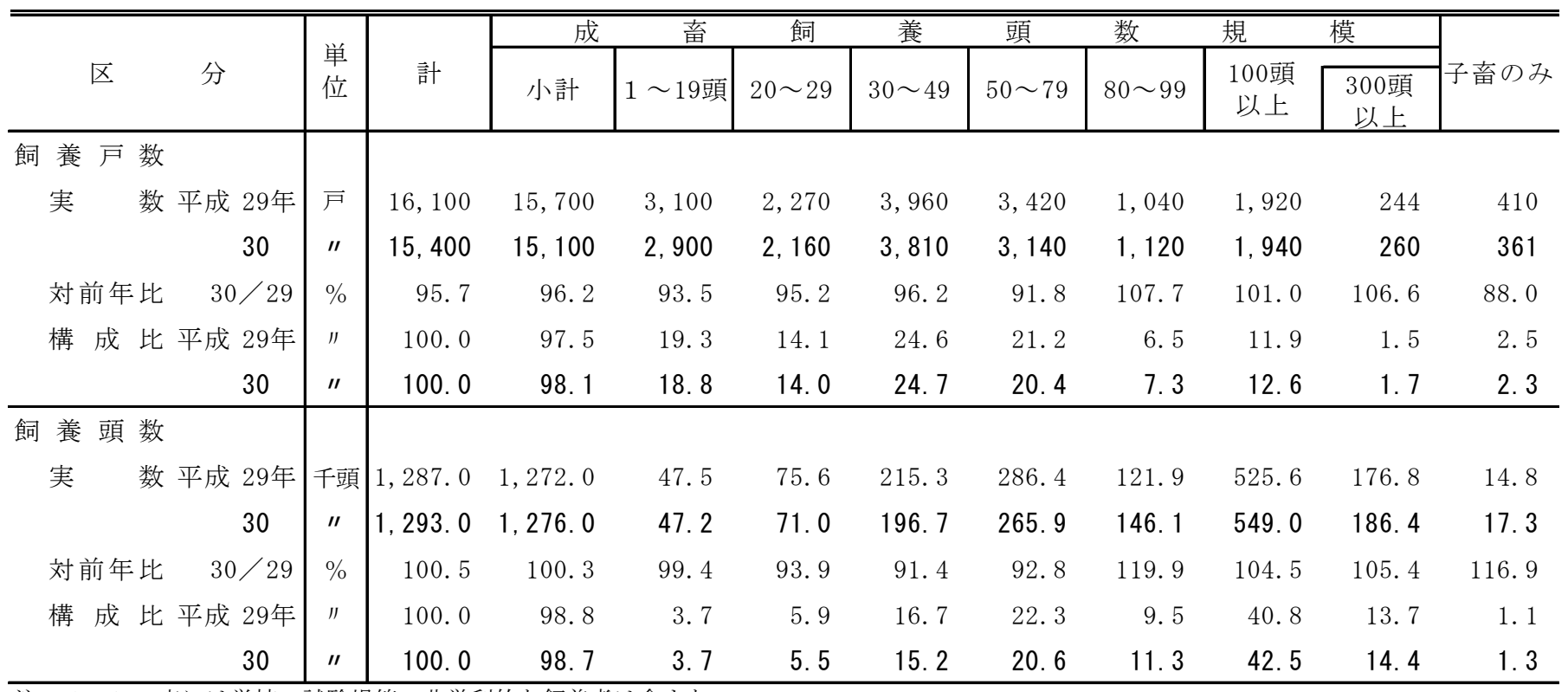

注 : 1 この表には学校、試験場等の非営利的な飼養者は含まない。

2 この表の飼養頭数は、各階層の飼養者が飼っている全ての乳用牛（成畜及び子畜）の頭数である。 
（4）乳用牛飼養者の飼料作物作付戸数と実面積の状況

乳用牛飼養者のうち、調査期日前の 1 年間（平成 29 年 2 月 1 日から平成 30 年 1 月 31 日まで。以 下同じ。）に飼料作物を作付けした戸数は 1 万 3,500 戸で、乳用牛飼養者の $87.7 \%$ となっており、 飼料作物作付実面積は47万8, 600ha となっている。

これを全国農業地域別にみると、北海道、東北及び九州において乳用牛飼養者の 9 割以上が飼 料作物を作付けしている。

\section{図 4 乳用牛飼養者の飼料作物作付戸数割合（全国農業地域別）}

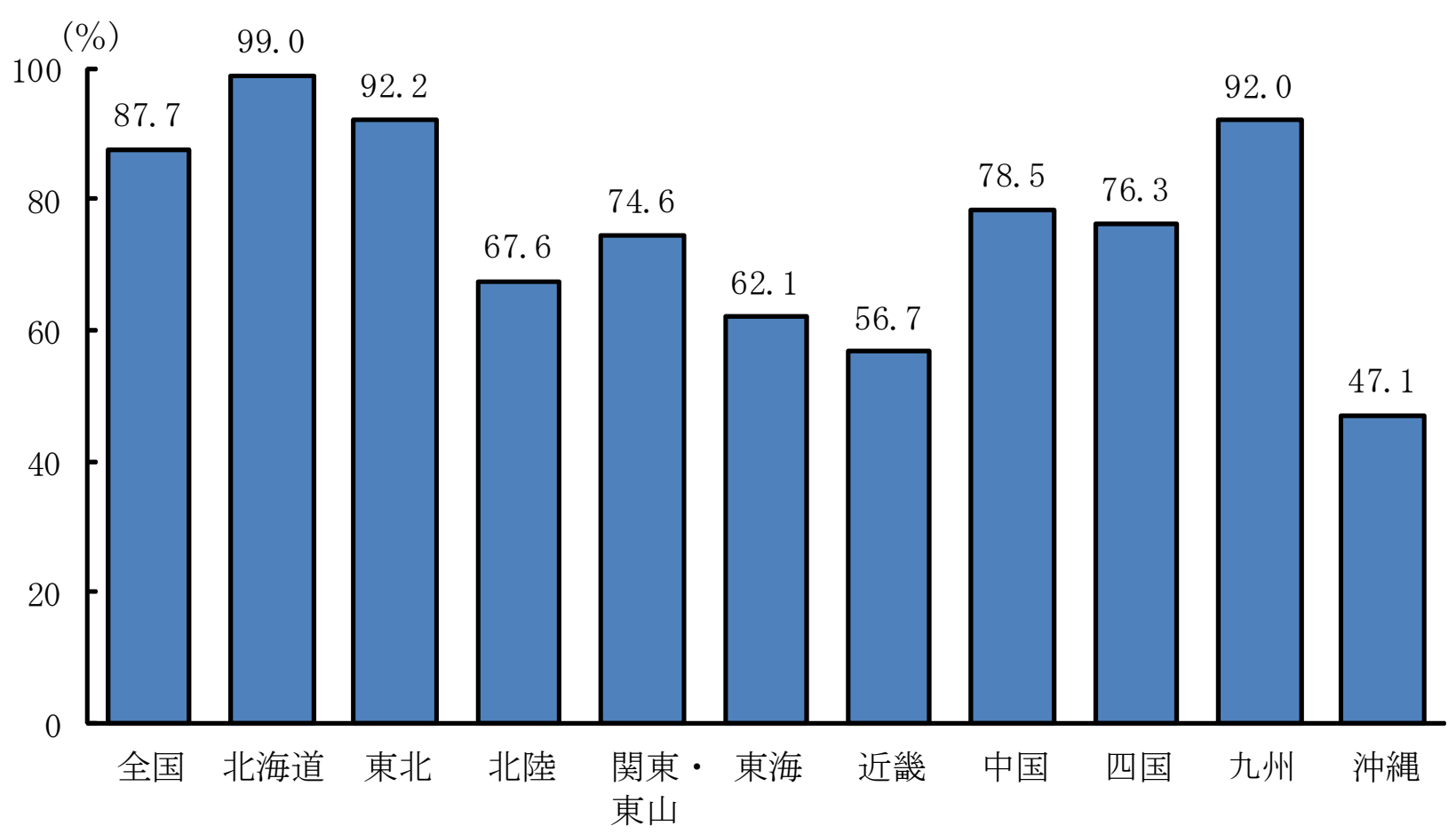

表 4 乳用牛飼養者の飼料作物作付戸数·実面積（全国農業地域別）

\begin{tabular}{|c|c|c|c|c|c|c|}
\hline 区 & 分 & 飼養戸数 & $\begin{array}{l}\text { 飼料 作物 } \\
\text { 作付 戸数 }\end{array}$ & $\begin{array}{l}\text { 飼料作物 } \\
\text { 作付 } \text { 戸数 } \\
\text { 割 }\end{array}$ & $\begin{array}{l}\text { 経 営耕地 } \\
\text { 面 }\end{array}$ & $\begin{array}{l}\text { 飼料作物 } \\
\text { 作付実面積 }\end{array}$ \\
\hline & & \multicolumn{2}{|l|}{ 戸 } & $\%$ & \multicolumn{2}{|l|}{ ha } \\
\hline 全 & 国 & 15,400 & 13,500 & 87.7 & 506,500 & 478,600 \\
\hline 北 浩 & 道 & 6,090 & 6,030 & 99.0 & 435,900 & 415,200 \\
\hline 東 & 北 & 2,320 & 2,140 & 92.2 & 30,000 & 27,500 \\
\hline 北 & 陸 & 309 & 209 & 67.6 & 1,730 & 1,460 \\
\hline 関東。 & • 東山 & 2,990 & 2,230 & 74.6 & 17,400 & 15,100 \\
\hline 東 & 海 & 665 & 413 & 62.1 & 2,370 & 2,120 \\
\hline 近 & 畿 & 469 & 266 & 56.7 & 720 & 500 \\
\hline 中 & 国 & 688 & 540 & 78.5 & 4,640 & 4,090 \\
\hline 四 & 国 & 346 & 264 & 76.3 & 990 & 850 \\
\hline 九 & 州 & 1,500 & 1,380 & 92.0 & 12,600 & 11,600 \\
\hline 沖 & 縄 & 68 & 32 & 47.1 & 170 & 130 \\
\hline
\end{tabular}

注:この表には学校、試験場等の非営利的な飼養者は含まない。 
（5）乳用牛の放牧状況

乳用牛飼養者のうち、調査期日前の 1 年間に乳用牛の放牧を行った戸数は 4,420 戸で、乳用牛 飼養者の $28.7 \%$ となっており、放牧頭数は 22 万 3,700 頭となっている。

これを全国農業地域別にみると、北海道では約 6 割の乳用牛飼養者が放牧を行っており、そ の他の地域を大きく上回っている。

図 5 乳用牛飼養者の放牧実施戸数割合（全国農業地域別）

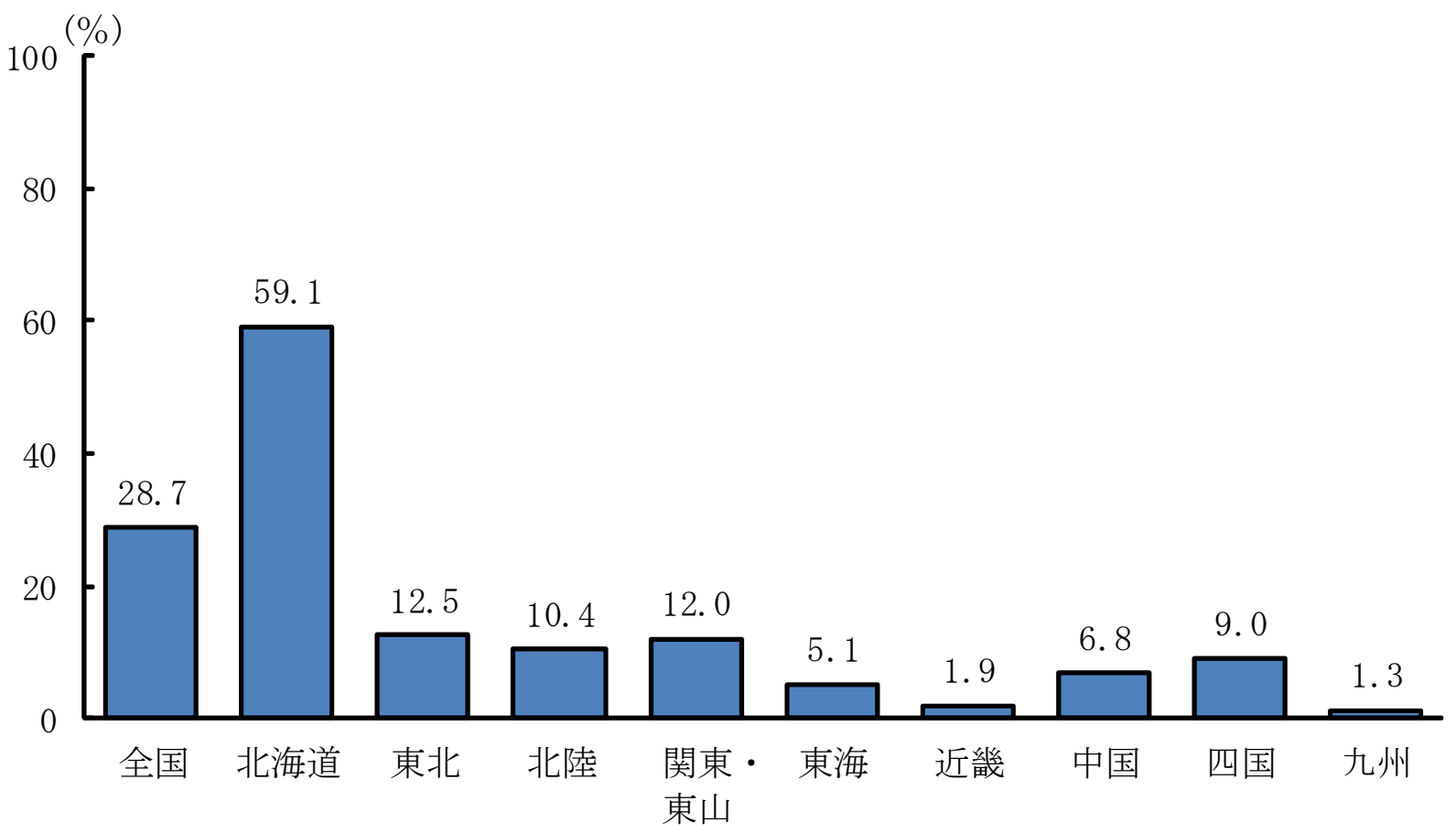

注 : 沖縄については、放牧している飼養者がいないため、表章していない。

表 5 乳用牛の放牧状況 （全国農業地域別）

\begin{tabular}{|c|c|c|c|c|c|}
\hline 区 & 分 & 飼 養 戸 数 & $\begin{array}{l}\text { 放牧をして } \\
\text { いる戸 数 }\end{array}$ & $\begin{array}{l}\text { 放 牧 実施 } \\
\text { 戸 数割合 }\end{array}$ & 放 牧 頭 数 \\
\hline & & 戸 & 戸 & $\%$ & 頭 \\
\hline 全 & 国 & 15,400 & 4,420 & 28.7 & 223,700 \\
\hline 北 海 & 道 & 6,090 & 3,600 & 59.1 & 209,500 \\
\hline 東 & 北 & 2,320 & 289 & 12.5 & 6,500 \\
\hline 北 & 陸 & 309 & 32 & 10.4 & 160 \\
\hline 関東 · 東 & 東山 & 2,990 & 359 & 12.0 & 4,550 \\
\hline 東 ～～～ & 海 & 665 & 34 & 5.1 & 740 \\
\hline 近 & 畿 & 469 & 9 & 1.9 & 140 \\
\hline 中 & 国 & 688 & 47 & 6.8 & 820 \\
\hline 四 & 国 & 346 & 31 & 9.0 & 540 \\
\hline 九 & 州 & 1,500 & 19 & 1.3 & 690 \\
\hline 沖 & 縄 & 68 & - & - & - \\
\hline
\end{tabular}

注:この表には学校、試験場等の非営利的な飼養者は含まない。 


\section{2 肉用牛}

(1) 飼養戸数 - 頭数

平成30年の全国の肉用牛の飼養戸数は 4 万 8,300 戸で、廃業等により前年に比べ $1,800 戸$ \%) 減少した。

飼養頭数は 251 万 4,000 頭で、前年に比べ 1 万 5,000 頭（ $0.6 \%)$ 増加した。飼養頭数の内訳をみ ると、肉用種は 170 万 1,000 頭で前年に比べ 3 万 7,000 頭（2.2\%）増加した。

このうち、子取り用めす牛は 61 万 400 頭、肥育用牛は 73 万 6,600 頭で、前年に比べそれぞれ 1 万 3,100 頭 $(2.2 \%) 、 1$ 万 4,300 頭 $(2.0 \%)$ 増加した。

乳用種（乳廃牛は除く。）は81万 3,000 頭で前年に比べ 2 万 1,700 頭（2.6\%）減少した。

また、乳用種のうち、ホルスタイン種他は29万5, 100頭で前年に比べ 1 万 8,000 頭（5.7\%）減 少し、交雑種（F 1 牛、F 1 クロス牛）は51万7, 900頭で前年に比べ 3 万 7, 000頭 $(0.7 \%$ ) 減少 した。

なお、 1 戸当たり飼養頭数は52.0頭で、前年に比べ2. 1頭増加した。

\section{図 6 肉用牛の飼養戸数・頭数の推移}
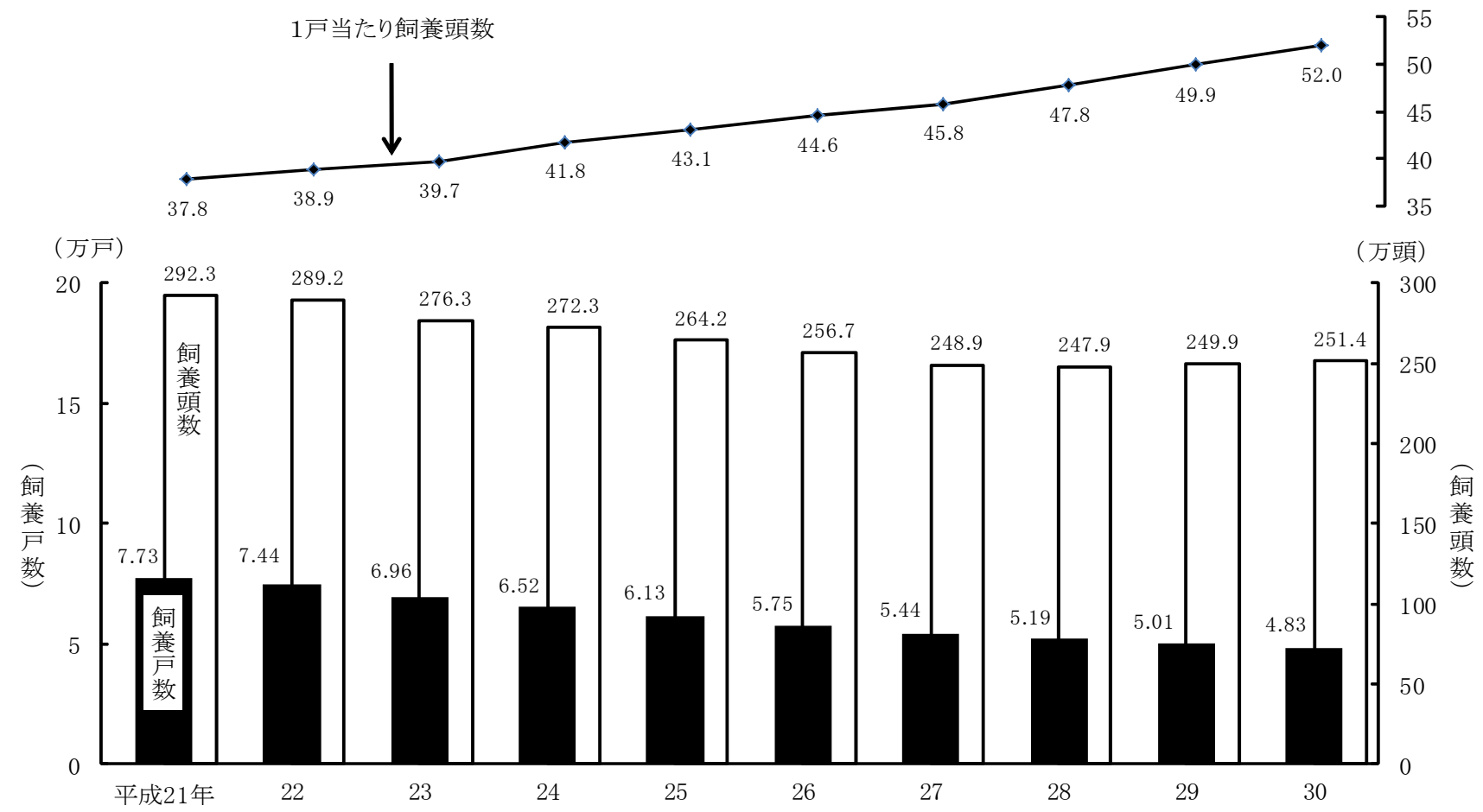

表 6 肉用牛の飼養戸数 ·頭数

\begin{tabular}{|c|c|c|c|c|c|c|c|c|c|c|}
\hline & \multirow{3}{*}{ 分 } & \multirow{3}{*}{ 飼養戸数 } & \multicolumn{4}{|c|}{ 飼 } & \multicolumn{3}{|c|}{ 数 } & \multirow{3}{*}{$\begin{array}{l}1 \text { 戸当たり } \\
\text { 飼養頭数 }\end{array}$} \\
\hline 区 & & & \multirow{2}{*}{ 計 } & \multirow{2}{*}{ 肉用種 } & & & 乳 & 用 & 種 & \\
\hline & & & & & 子取り用めす牛 & 肥育用牛 & 計 & ホルスタインン種他 & 交雑種 & \\
\hline & & 戸 & 千頭 & 千頭 & 千頭 & 千頭 & 千頭 & 千頭 & 千頭 & 頭 \\
\hline 実 & 数 & & & & & & & & & \\
\hline & 平成28年 & 51,900 & $2,479.0$ & $1,642.0$ & 589.1 & 720.0 & 837.1 & 331.8 & 505.3 & 47.8 \\
\hline & 29 & 50,100 & $2,499.0$ & $1,664.0$ & 597.3 & 722.3 & 834.7 & 313.1 & 521.6 & 49.9 \\
\hline & 30 & 48,300 & $2,514.0$ & $1,701.0$ & 610.4 & 736.6 & 813.0 & 295.1 & 517.9 & 52.0 \\
\hline 対前年比 & & & & & & & & & & \\
\hline & $30 / 29(\%)$ & 96.4 & 100.6 & 102.2 & 102.2 & 102.0 & 97.4 & 94.3 & 99.3 & - \\
\hline 洅 分地 & 平成28年（\%) & - & 100.0 & 66.2 & 23.8 & 29.0 & 33.8 & 13.4 & 20.4 & - \\
\hline & 29 & - & 100.0 & 66.6 & 23.9 & 28.9 & 33.4 & 12.5 & 20.9 & - \\
\hline & 30 & - & 100.0 & 67.7 & 24. 3 & 29.3 & 32.3 & 11.7 & 20.6 & - \\
\hline
\end{tabular}


（2） 全国農業地域別飼養戸数・頭数

全国農業地域別にみると、肉用牛の飼養戸数は、前年に比べ全ての地域では減少した。

飼養頭数は、前年に比べ東北、北陸、関東・東山及び東海で減少したが、これ以外の地域で は増加した。

なお、地域別の飼養頭数割合は、九州が全国の約 4 割を占めている。

図 7 肉用牛の全国農業地域別飼養戸数・頭数の前年比較

一飼養戸数一

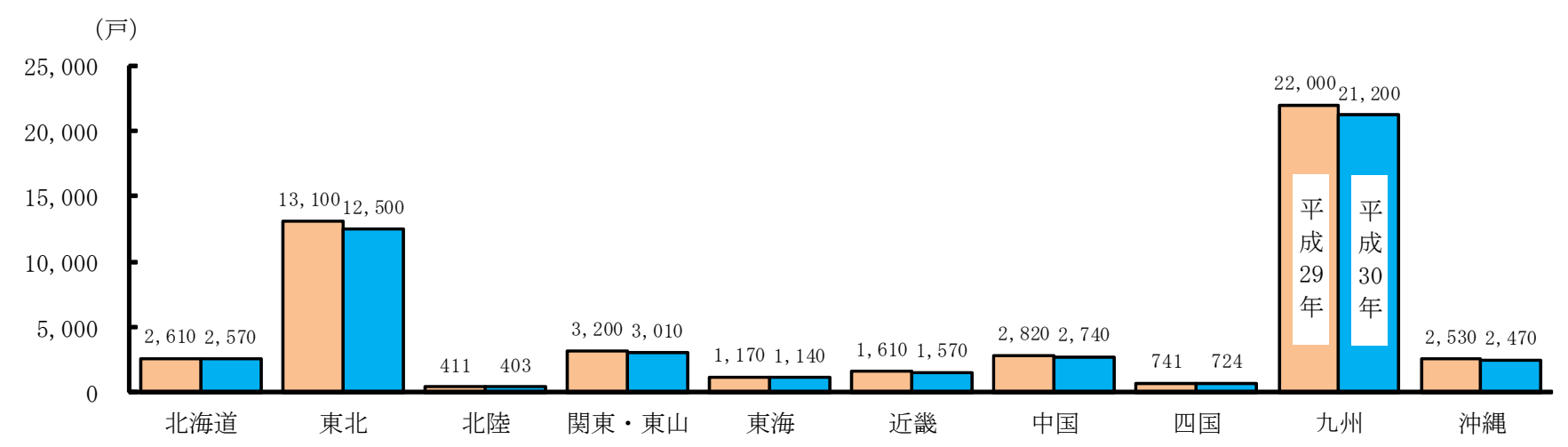

一飼養頭数一

(千頭)

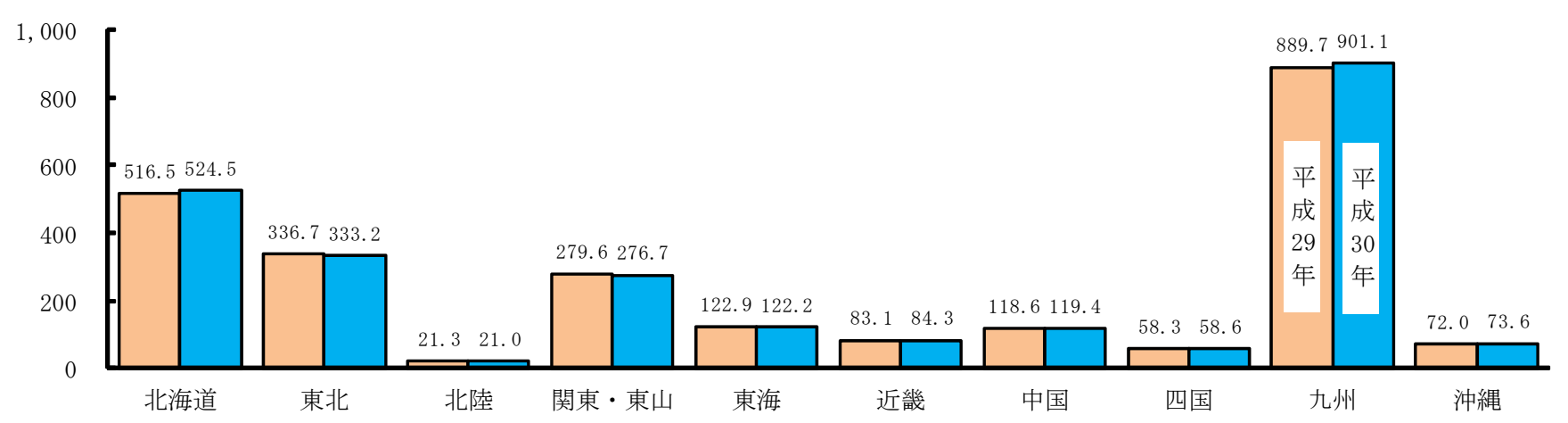

表 7 肉用牛の全国農業地域別飼養戸数 - 頭数

\begin{tabular}{|c|c|c|c|c|c|c|c|c|c|c|c|c|c|}
\hline 区 & 分 & 単位 & 全 国 & 北海道 & 東 北 & 北 陸 & $\begin{array}{l}\text { 関 東 } \\
\text { 東 山 }\end{array}$ & 東 海 & 近 畿 & 中 国 & 四 国 & 九 州 & 沖 縄 \\
\hline \multicolumn{14}{|l|}{ 飼 養 戸 数 } \\
\hline \multirow{2}{*}{ 実 数 } & 滧 平成 29年 & 戸 & 50,100 & 2,610 & 13,100 & 411 & 3,200 & 1,170 & 1,610 & 2,820 & 741 & 22,000 & 2,530 \\
\hline & 30 & $\prime \prime$ & 48,300 & 2,570 & 12,500 & 403 & 3,010 & 1,140 & 1,570 & 2,740 & 724 & 21,200 & 2,470 \\
\hline 対前年比 & 七 $30 / 29$ & $\%$ & 96.4 & 98.5 & 95.4 & 98.1 & 94.1 & 97.4 & 97.5 & 97.2 & 97.7 & 96.4 & 97.6 \\
\hline \multirow{2}{*}{ 全国割合 } & 合平成 29 年 & $"$ & 100.0 & 5.2 & 26.1 & 0.8 & 6.4 & 2.3 & 3.2 & 5.6 & 1.5 & 43.9 & 5.0 \\
\hline & 30 & $\prime \prime$ & 100.0 & 5.3 & 25.9 & 0.8 & 6.2 & 2. 4 & 3.3 & 5.7 & 1.5 & 43.9 & 5.1 \\
\hline \multicolumn{14}{|c|}{\begin{tabular}{l|l|l|l|l|l|l|l|l|} 
養 頭 数 & &
\end{tabular}} \\
\hline \multirow[t]{2}{*}{ 実 数 } & 效平成 29 年 & 千頭 & $2,499.0$ & 516.5 & 336.7 & 21.3 & 279.6 & 122.9 & 83.1 & 118.6 & 58.3 & 889.7 & 72.0 \\
\hline & 30 & $\prime \prime$ & $2,514.0$ & 524.5 & 333.2 & 21.0 & 276.7 & 122.2 & 84.3 & 119.4 & 58.6 & 901.1 & 73.6 \\
\hline 対前年比 & $30 / 29$ & $\%$ & 100.6 & 101.5 & 99.0 & 98.6 & 99.0 & 99.4 & 101.4 & 100.7 & 100.5 & 101.3 & 102.2 \\
\hline \multirow[t]{2}{*}{ 全国割合 } & 平成 29 年 & $"$ & 100.0 & 20.7 & 13.5 & 0.9 & 11.2 & 4.9 & 3.3 & 4.7 & 2.3 & 35.6 & 2.9 \\
\hline & 30 & " & 100.0 & 20.9 & 13. 3 & 0.8 & 11.0 & 4. 9 & 3.4 & 4. 7 & 2. 3 & 35.8 & 2.9 \\
\hline
\end{tabular}




\section{（3） 総飼養頭数規模別飼養戸数・頭数}

ア 総飼養頭数規模別飼養戸数・頭数

肉用牛の総飼養頭数規模別（学校、試験場等の非営利的な飼養者を含まない。以下イ及びウ 並びに(4) 及び(5)において同じ。）にみると、飼養戸数は、前年に比べ20〜49頭の階層で増加 したが、これ以外の階層では減少した。

飼養頭数は、前年に比べ20～49頭、100〜 199頭及び200頭以上の階層で増加したが、これ以 外の階層では減少した。

なお、総飼養頭数規模別の飼養頭数割合は、200頭以上の階層が約 6 割を占めている。

\section{図 8 肉用牛の総飼養頭数規模別飼養戸数・頭数の前年比較}

一飼養戸数一

\section{(戸)}

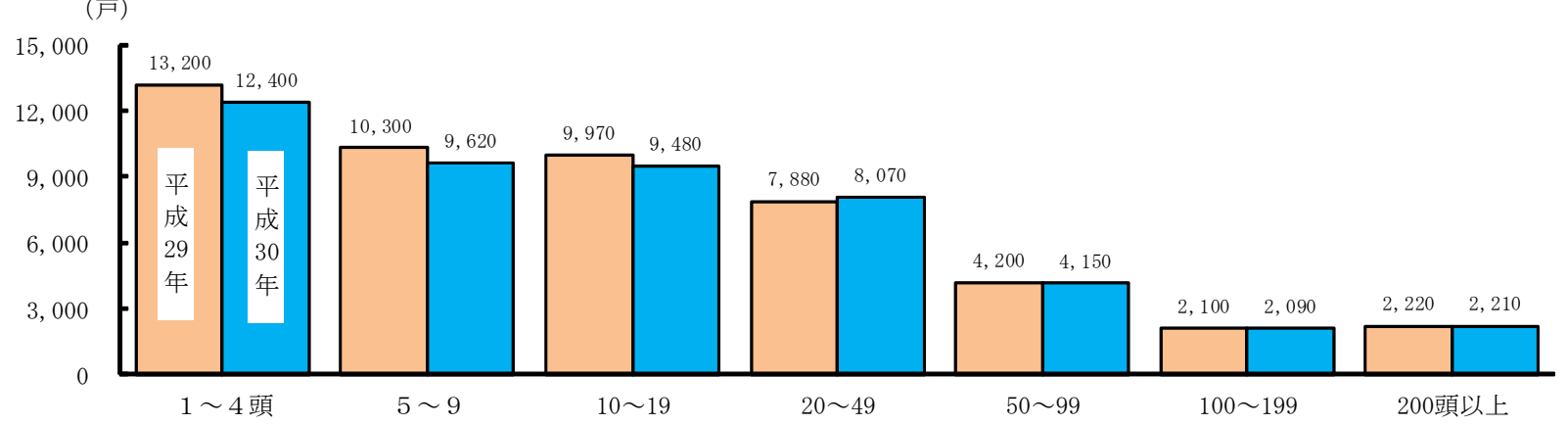

一飼養頭数一

(千頭)

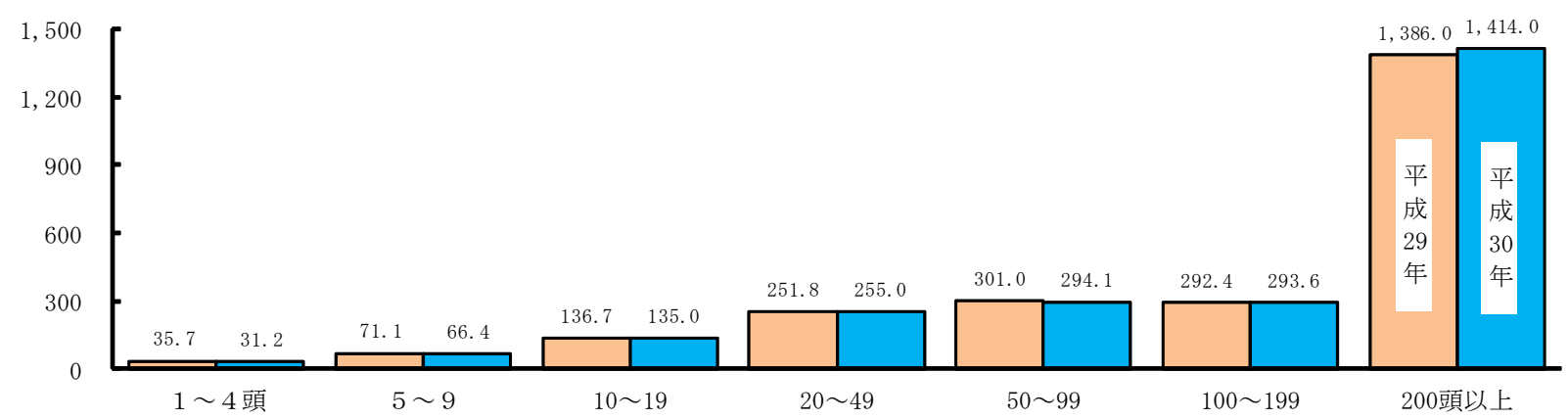

表 8 肉用牛の総飼養頭数規模別飼養戸数・頭数

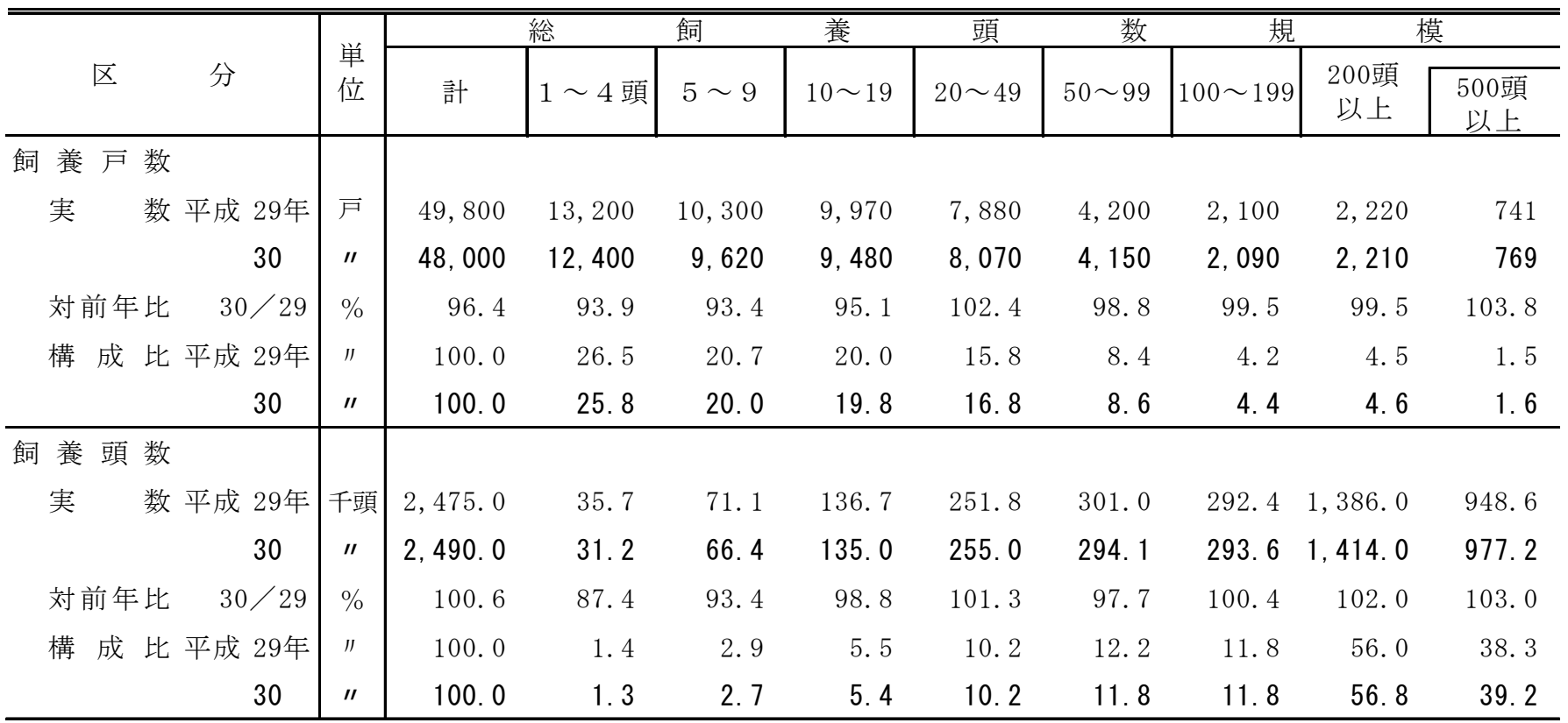

注 : この表には学校、試験場等の非営利的な飼養者は含まない。 
1 肉用種の目的別飼養頭数別飼養戸数

（ア）子取り用めす牛

肉用種の子取り用めす牛を飼養している戸数は 4 万 1,800 戸で、肉用牛飼養戸数の $87.1 \%$ と なっている。

飼養頭数規模別にみると、前年に比べて 10〜 19頭、20～49頭、50～99頭及び100頭以上の階 層で増加したが、これ以外の階層では減少した。

\section{表 9 子取り用めす牛の飼養頭数規模別飼養戸数}

\begin{tabular}{|c|c|c|c|c|c|c|c|c|c|c|}
\hline \multirow{2}{*}{ 区 } & \multirow{2}{*}{ 分 } & \multirow{2}{*}{$\begin{array}{l}\text { 肉用牛の } \\
\text { 飼養戸数 }\end{array}$} & 子 & $y$ & 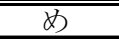 & 牛 & 養 & 数 & 模 & \multirow{2}{*}{$\begin{array}{l}\text { 子取り用 } \\
\text { めす 牛 } \\
\text { な し }\end{array}$} \\
\hline & & & 計 & $1 \sim 4$ 頭 & $5 \sim 9$ & $10 \sim 19$ & $20 \sim 49$ & $50 \sim 99$ & 100 頭以上 & \\
\hline \multirow[t]{2}{*}{ 実 } & 敕 平成29年 & 49,800 & 43,000 & 18,400 & 10,400 & 7,170 & 5,200 & 1,370 & 495 & 6,790 \\
\hline & 30 & 48,000 & 41,800 & 16,600 & 10,000 & 7,780 & 5,350 & 1,570 & 539 & 6,190 \\
\hline 対前年比 & $30 / 29(\%)$ & 96.4 & 97.2 & 90.2 & 96.2 & 108.5 & 102.9 & 114.6 & 108.9 & 91.2 \\
\hline \multirow[t]{2}{*}{ 構 成 上 } & 比平成29年（\%) & 100.0 & 86.3 & 36.9 & 20.9 & 14. 4 & 10.4 & 2.8 & 1.0 & 13.6 \\
\hline & 30 & 100.0 & 87.1 & 34.6 & 20.8 & 16. 2 & 11.1 & 3.3 & 1.1 & 12.9 \\
\hline
\end{tabular}

注 : この表には学校、試駼場等の非営利的な飼養者は含まない。

（イ）肥育用牛

肉用種の肥育用牛を飼養している戸数は7, 620戸で、肉用牛飼養戸数の $15.9 \%$ となっている。

飼養頭数規模別にみると、前年に比べて $1 \sim 9$ 頭及び200頭以上の階層で増加したが、これ

以外の階層では減少した。

表10 肥育用牛の飼養頭数規模別飼養戸数

\begin{tabular}{|c|c|c|c|c|c|c|c|c|c|c|c|c|c|}
\hline \multirow{2}{*}{\multicolumn{2}{|c|}{ 区 }} & \multirow[b]{2}{*}{ 分 } & \multirow[b]{2}{*}{$\begin{array}{l}\text { 肉用牛の } \\
\text { 飼養戸数 }\end{array}$} & 肥 & 育 & 用 & 牛 & 飼 & 頭 & 数 & 規 & $\begin{array}{c}\text { 模 } \\
\end{array}$ & \multirow[b]{2}{*}{$\begin{array}{l}\text { 肥育用牛 } \\
\text { な し }\end{array}$} \\
\hline & & & & 計 & $1 \sim 9$ 頭 & $10 \sim 19$ & $20 \sim 29$ & $30 \sim 49$ & $50 \sim 99$ & $100 \sim 199$ & $\begin{array}{c}200 \text { 頭 } \\
\text { 以上 }\end{array}$ & $\begin{array}{c}\text { 500頭 } \\
\text { 以上 }\end{array}$ & \\
\hline \multirow[t]{2}{*}{ 実 } & 数 平 & 平成29年 & 49,800 & 7,840 & 2,570 & 817 & 594 & 897 & 1,110 & 944 & 904 & 255 & 42,000 \\
\hline & & 30 & 48,000 & 7,620 & 2,640 & 733 & 514 & 781 & 1,100 & 884 & 969 & 304 & 40,400 \\
\hline \multirow{2}{*}{\multicolumn{3}{|c|}{$\begin{array}{l}\text { 対前年比 } 30 / 29(\%) \\
\text { 構 成 比 平成29年 }(\%)\end{array}$}} & 96.4 & 97.2 & 102.7 & 89.7 & 86.5 & 87.1 & 99.1 & 93.6 & 107.2 & 119.2 & 96.2 \\
\hline & & & 100.0 & 15.7 & 5.2 & 1.6 & 1.2 & 1.8 & 2.2 & 1.9 & 1.8 & 0.5 & 84.3 \\
\hline \multicolumn{3}{|r|}{30} & 100.0 & 15.9 & 5.5 & 1.5 & 1.1 & 1.6 & 2. 3 & 1.8 & 2. 0 & 0.6 & 84.2 \\
\hline
\end{tabular}

注：この表には学校、試験場等の非営利的な飼養者は含まない。

ウ 乳用種の飼養頭数規模別飼養戸数

肉用の乳用種を飼養している戸数は 4,650 戸で、肉用牛飼養戸数の $9.7 \%$ となっている。

飼養頭数規模別にみると、前年に比べて 50～99頭及び100～199頭の階層で増加したが、これ以

外の階層では減少した。

\section{表11 乳用種の飼養頭数規模別飼養戸数}

\begin{tabular}{|c|c|c|c|c|c|c|c|c|c|c|c|}
\hline \multirow[b]{2}{*}{ 区 } & \multirow[b]{2}{*}{ 分 } & \multirow[b]{2}{*}{$\begin{array}{l}\text { 肉用牛の } \\
\text { 飼養戸数 }\end{array}$} & 乳 & 甬 & 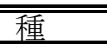 & 飼 & 頭 & 数 & 規 & 模 & \multirow[b]{2}{*}{$\begin{array}{l}\text { 乳用種 } \\
\text { な し }\end{array}$} \\
\hline & & & 計 & $1 \sim 4$ 頭 & $5 \sim 19$ & $20 \sim 49$ & $50 \sim 99$ & $100 \sim 199$ & $\begin{array}{l}200 \text { 頭 } \\
\text { 以上 }\end{array}$ & $\begin{array}{c}\text { 500頭 } \\
\text { 以上 }\end{array}$ & \\
\hline & 校 平成29年 & 49,800 & 4,950 & 1,540 & 909 & 619 & 423 & 480 & 975 & 404 & 44,900 \\
\hline & 30 & 48,000 & 4,650 & 1,440 & 888 & 486 & 427 & 491 & 914 & 408 & 43,300 \\
\hline \multirow{2}{*}{\multicolumn{2}{|c|}{$\begin{array}{l}\text { 対前年比 } 30 / 29(\%) \\
\text { 構 成 比 平成29年 }(\%)\end{array}$}} & 96.4 & 93.9 & 93.5 & 97.7 & 78.5 & 100.9 & 102.3 & 93.7 & 101.0 & 96.4 \\
\hline & & 100.0 & 9.9 & 3. 1 & 1.8 & 1.2 & 0.8 & 1.0 & 2.0 & 0.8 & 90.2 \\
\hline \multicolumn{2}{|r|}{30} & 100.0 & 9.7 & 3. 0 & 1.9 & 1.0 & 0.9 & 1.0 & 1.9 & 0.9 & 90.2 \\
\hline
\end{tabular}

注：この表には学校、試験場等の非営利的な飼養者は含まない。 
（4） 肉用牛飼養者の飼料作物作付戸数と実面積の状況

肉用牛飼養者のうち、調査期日前の 1 年間に飼料作物を作付けした戸数は 3 万 9,000 戸で、肉 用牛飼養者の $81.3 \%$ となっており、飼料作物作付実面積は 19 万 $5,800 \mathrm{ha}$ となっている。

これを全国農業地域別にみると、北海道及び九州で肉用牛飼養者の約 9 割が飼料作物を作付け している。

図 9 肉用牛飼養者の飼料作物作付戸数割合（全国農業地域別）

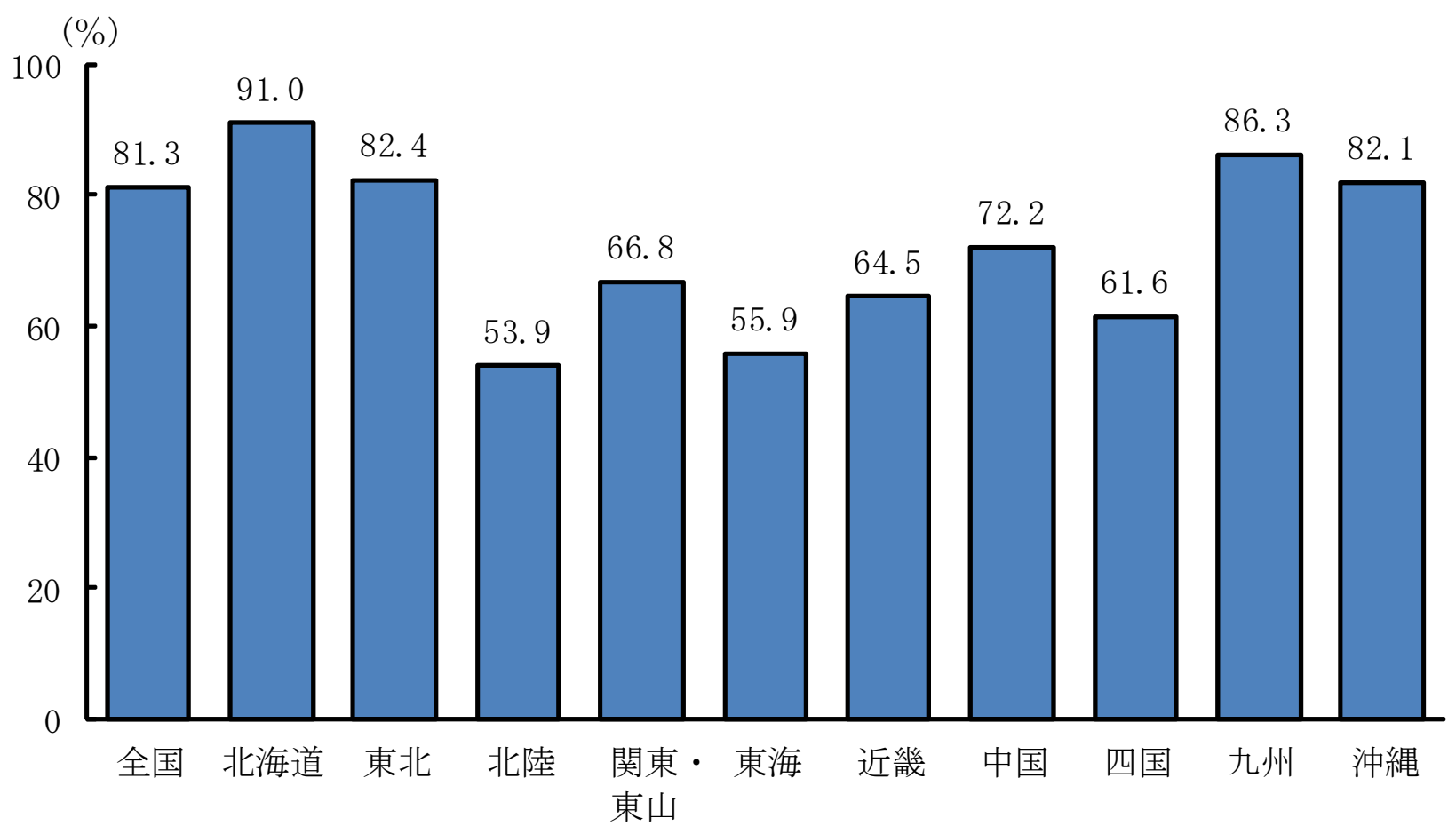

表12 肉用牛飼養者の飼料作物作付戸数・実面積（全国農業地域別）

\begin{tabular}{|c|c|c|c|c|c|c|}
\hline 区 & 分 & 飼養戸数 & $\begin{array}{l}\text { 飼 料 作物 } \\
\text { 作付 戸数 }\end{array}$ & $\begin{array}{l}\text { 飼料作物 } \\
\text { 作付 戸数 } \\
\text { 割 }\end{array}$ & $\begin{array}{l}\text { 経営耕地 } \\
\text { 面 積 }\end{array}$ & $\begin{array}{l}\text { 飼料 作物 } \\
\text { 作付実面積 }\end{array}$ \\
\hline & & $\overline{\text { 戸 }}$ & $\overline{\text { 戸 }}$ & $\%$ & ha & ha \\
\hline 全 & 国 & 48,000 & 39,000 & 81.3 & 272,900 & 195,800 \\
\hline 北 治 & 道 & 2,550 & 2,320 & 91.0 & 101,800 & 83,100 \\
\hline 東 & 北 & 12,500 & 10,300 & 82.4 & 71,200 & 36,200 \\
\hline 北 & 陸 & 384 & 207 & 53.9 & 1,310 & 770 \\
\hline 関 東 & 東山 & 2,950 & 1,970 & 66.8 & 13,700 & 8,330 \\
\hline 東 & 海 & 1,110 & 620 & 55.9 & 2,120 & 1,500 \\
\hline 近 & 畿 & 1,550 & 1,000 & 64.5 & 1,570 & 790 \\
\hline 中 & 国 & 2,700 & 1,950 & 72.2 & 6,810 & 3,820 \\
\hline 四 & 国 & 711 & 438 & 61.6 & 1,250 & 660 \\
\hline 九 & 州 & 21,100 & 18,200 & 86.3 & 66,600 & 55,000 \\
\hline 沖 & 縄 & 2,460 & 2,020 & 82.1 & 6,560 & 5,680 \\
\hline
\end{tabular}

注:この表には学校、試験場等の非営利的な飼養者は含まない。 
（5）肉用牛の放牧状況

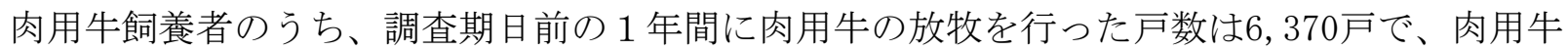
飼養者の $13.3 \%$ となっており、放牧頭数は 8 万 7,900 頭となっている。

これを全国農業地域別にみると、北海道では約 4 割の肉用牛飼養者が放牧を行っている。

\section{図10 肉用牛飼養者の放牧実施戸数割合（全国農業地域別）}

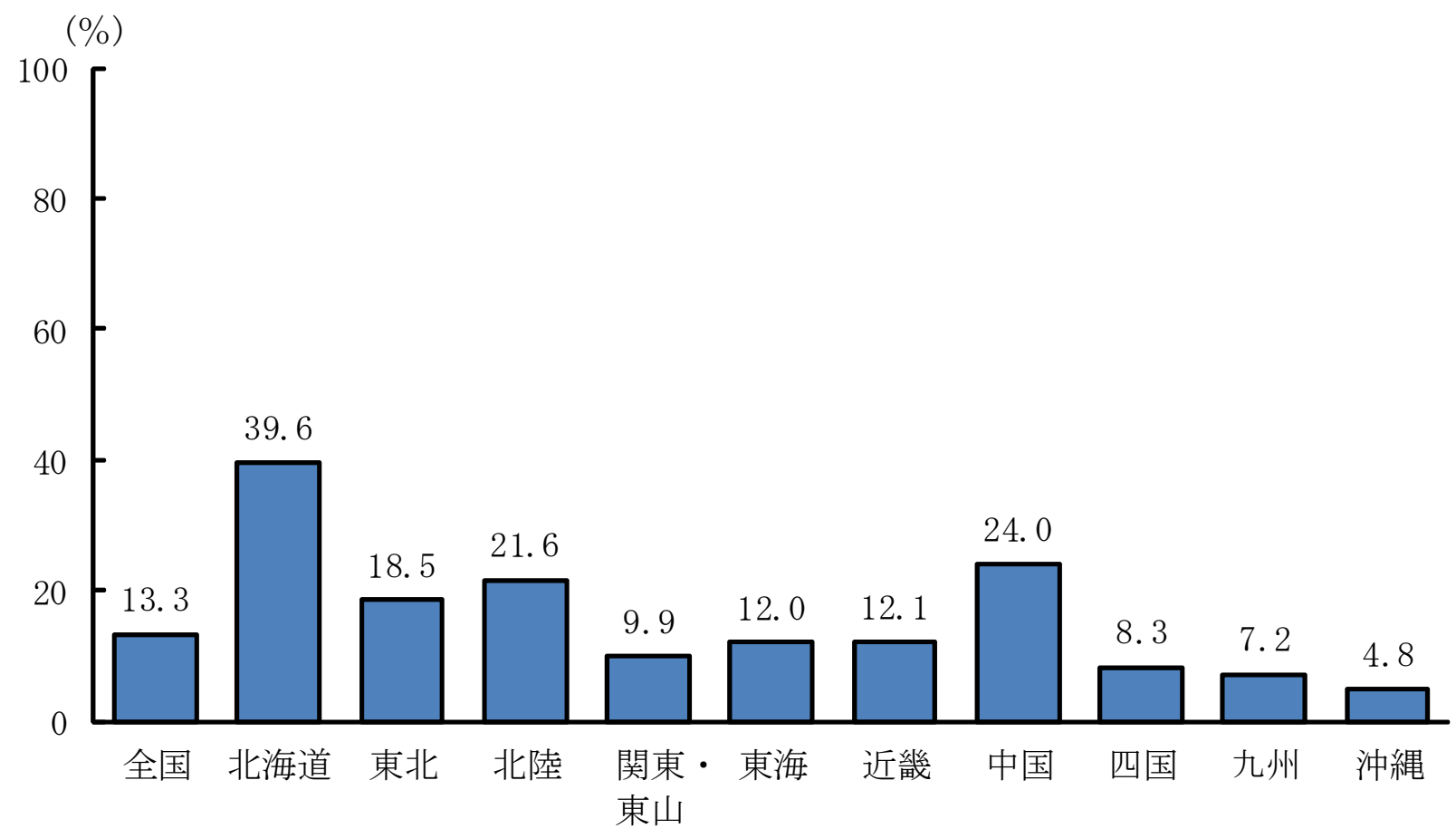

表13 肉用牛の放牧状況（全国農業地域別）

\begin{tabular}{|c|c|c|c|c|c|}
\hline 区 & 分 & 飼 養 戸 数 & $\begin{array}{l}\text { 放牧をして } \\
\text { いる戸 数 }\end{array}$ & $\begin{array}{l}\text { 放 牧 実 施 } \\
\text { 戸 数 割 合 }\end{array}$ & 放 牧 頭 数 \\
\hline & & 戸 & 戸 & $\%$ & 頭 \\
\hline 全 & 国 & 48,000 & 6,370 & 13.3 & 87,900 \\
\hline 北 海 & 道 & 2,550 & 1,010 & 39.6 & 35,800 \\
\hline 東 & 北 & 12,500 & 2,310 & 18.5 & 21,100 \\
\hline 北 & 陸 & 384 & 83 & 21.6 & 430 \\
\hline 関東 • & 東山 & 2,950 & 292 & 9.9 & 3,360 \\
\hline 東 & 海 & 1,110 & 133 & 12.0 & 1,100 \\
\hline 近 & 畿 & 1,550 & 188 & 12.1 & 2,460 \\
\hline 中 & 国 & 2,700 & 647 & 24.0 & 6,050 \\
\hline 四 & 国 & 711 & 59 & 8.3 & 460 \\
\hline 九 & 州 & 21,100 & 1,520 & 7.2 & 13,700 \\
\hline 沖 & 縄 & 2,460 & 119 & 4.8 & 3,450 \\
\hline
\end{tabular}

注:この表には学校、試験場等の非営利的な飼養者は含まない。 
3 豚

(1) 飼養戸数・頭数

平成30年の全国の豚の飼養戸数は4, 470戸で、廃業等により前年に比べ200戸（4.3\%）減少し た。

飼養頭数は 918 万 9,000 頭で、前年に比べ 15 万 7,000 頭（1.7\%）減少した。飼養頭数の内訳をみ ると、子取り用めす豚は 82 万 3,700 頭で、前年に比べ 1 万 5,600 頭（1.9\%）減少し、肥育豚は 767 万 7, 000頭で、前年に比 12 万頭 (1.5\%) 減少した。

なお、 1 戸当たり飼養頭数は2, 055.7頭で、前年に比べ54.4頭増加した。

\section{図11 豚の飼養戸数・頭数の推移}
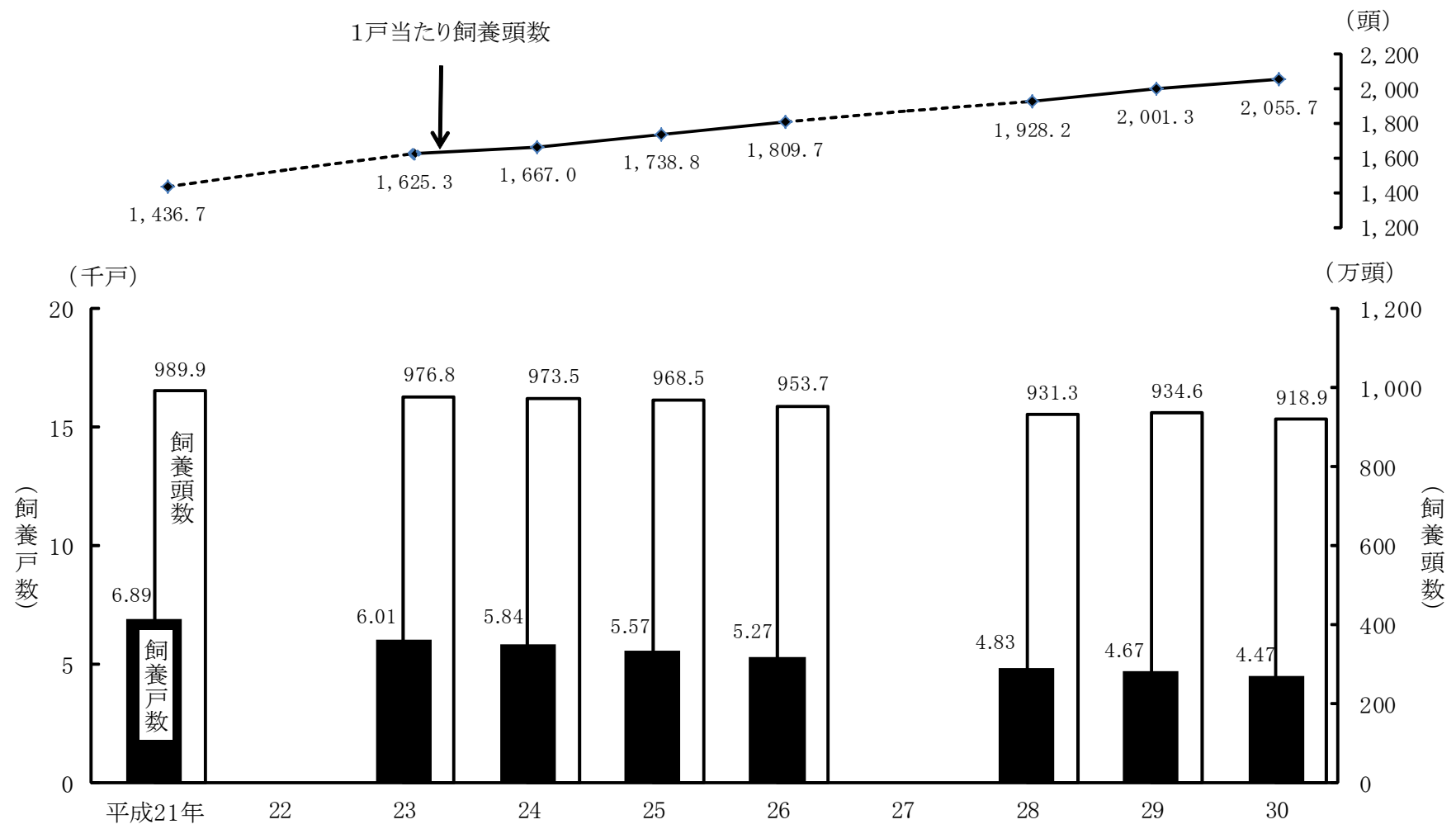

注 : 平成22年は2010年世界農林業センサス、平成27年は2015年農林業センサス実施年のため、調査を休止した。

表14 豚の飼養戸数・頭数

\begin{tabular}{|c|c|c|c|c|c|c|c|c|c|c|}
\hline & \multirow[b]{2}{*}{ 分 } & \multirow[b]{2}{*}{ 飼養戸数 } & & \multicolumn{2}{|l|}{ 飼 } & \multicolumn{2}{|c|}{ 頭 } & 数 & \multirow[b]{2}{*}{$\begin{array}{l}1 \text { 戸当たり } \\
\text { 飼養頭数 }\end{array}$} & \multirow[b]{2}{*}{$\begin{array}{c}\text { 子取り用 } \\
\text { めす豚 }\end{array}$} \\
\hline 区 & & & $\begin{array}{l}\text { 子取り用 } \\
\text { めす豚の } \\
\text { いる戸数 }\end{array}$ & 計 & $\begin{array}{c}\text { 子取り用 } \\
\text { めす豚 }\end{array}$ & 種おす豚 & 肥育豚 & その他 & & \\
\hline 実 & 数 & 戸 & 戸 & 千頭 & 千頭 & 千頭 & 千磌 & 千頭 & 頭 & 頭 \\
\hline & 平成28年 & 4,830 & 3,940 & $9,313.0$ & 844.7 & 42.6 & $7,743.0$ & 682.5 & $1,928.2$ & 214.4 \\
\hline & 29 & 4,670 & 3,800 & $9,346.0$ & 839.3 & 43.5 & $7,797.0$ & 666.1 & $2,001.3$ & 220.9 \\
\hline 対前年比 & 30 & 4,470 & 3,640 & $9,189.0$ & 823.7 & 39.4 & $7,677.0$ & 649.6 & $2,055.7$ & 226.3 \\
\hline 構 成 上 & 比 $30 / 29(\%)$ & 95.7 & 95.8 & 98.3 & 98.1 & 90.6 & 98.5 & 97.5 & - & - \\
\hline & 平成28年（\%) & 100.0 & 81.6 & 100.0 & 9.1 & 0.5 & 83.1 & 7.3 & - & - \\
\hline & 29 & 100.0 & 81.4 & 100.0 & 9.0 & 0.5 & 83.4 & 7.1 & - & - \\
\hline & 30 & 100.0 & 81.4 & 100.0 & 9.0 & 0.4 & 83.5 & 7. 1 & - & - \\
\hline
\end{tabular}


（2） 全国農業地域別飼養戸数・頭数

全国農業地域別にみると、豚の飼養戸数は、前年に比べ全ての地域で減少した。

飼養頭数は、前年に比べ東海、中国及び沖縄で増加したが、これ以外の地域では減少した。

なお、地域別の飼養頭数割合は、関東・東山及び九州が、それぞれ全国の約 3 割を占めてい る。

\section{図12＼cjkstart豚の全国農業地域別飼養戸数・頭数の前年比較}

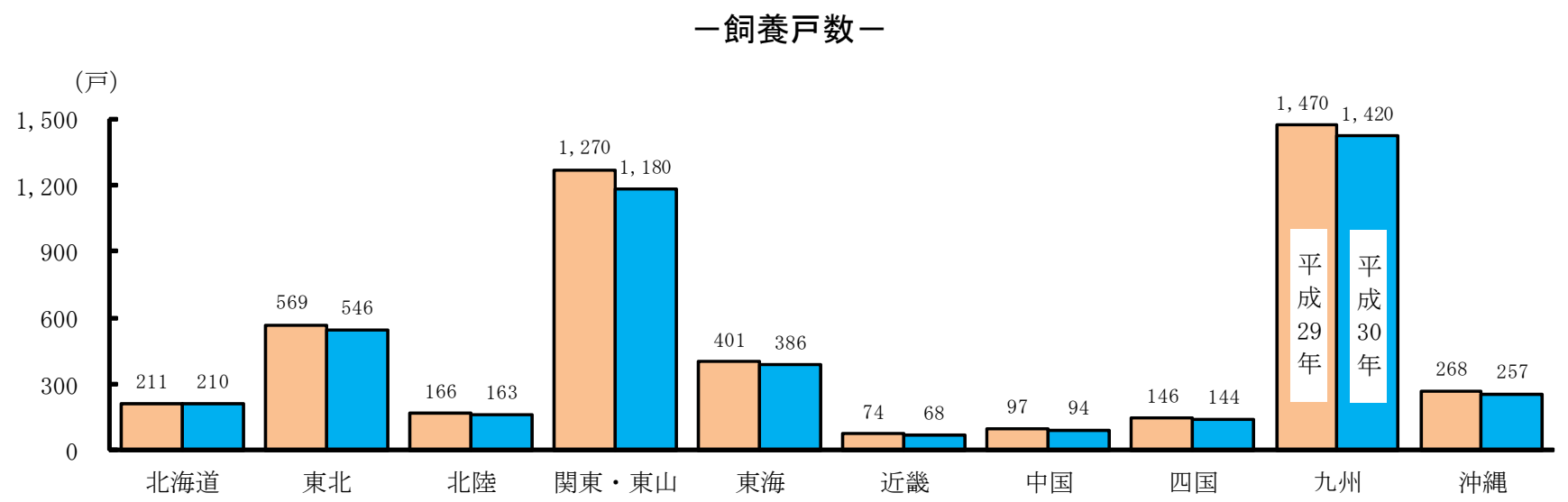

一飼養頭数一

(千頭)

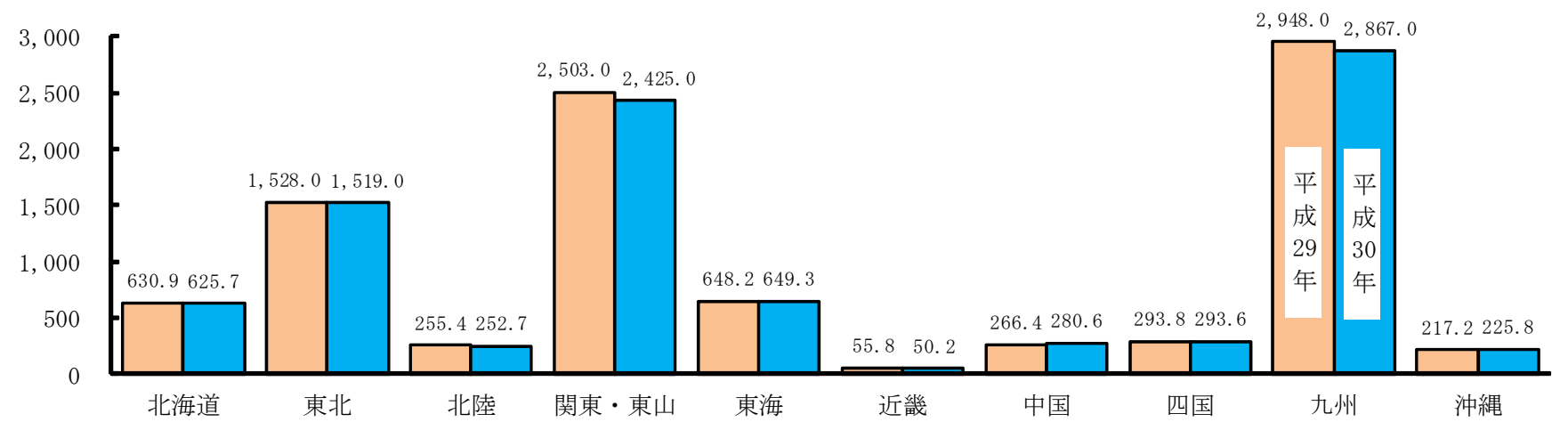

表15 豚の全国農業地域別飼養戸数・頭数

\begin{tabular}{|c|c|c|c|c|c|c|c|c|c|c|c|c|c|}
\hline 区 & 分 & 単位 & 全 国 & 北海道 & 東 北 & 北 陸 & $\begin{array}{l}\text { 関 東 } \\
\text { 東 山 }\end{array}$ & 東 海 & 近 畿 & 中 国 & 四 国 & 九 州 & 沖 縄 \\
\hline \multicolumn{14}{|c|}{ 飼 養 戸 数 } \\
\hline \multirow[t]{2}{*}{ 実 数 } & 文平成 29 年 & 戸 & 4,670 & 211 & 569 & 166 & 1,270 & 401 & 74 & 97 & 146 & 1,470 & 268 \\
\hline & 30 & $"$ & 4,470 & 210 & 546 & 163 & 1,180 & 386 & 68 & 94 & 144 & 1,420 & 257 \\
\hline 対前年比 & ᄂ $\quad 30 / 29$ & $\%$ & 95.7 & 99.5 & 96.0 & 98.2 & 92.9 & 96.3 & 91.9 & 96.9 & 98.6 & 96.6 & 95.9 \\
\hline \multirow[t]{2}{*}{ 全国割合 } & 平成 29 年 & $"$ & 100.0 & 4.5 & 12.2 & 3.6 & 27.2 & 8.6 & 1.6 & 2.1 & 3.1 & 31.5 & 5.7 \\
\hline & 30 & " & 100.0 & 4. 7 & 12. 2 & 3. 6 & 26.4 & 8. 6 & 1.5 & 2. 1 & 3. 2 & 31.8 & 5.7 \\
\hline \multicolumn{14}{|l|}{ 飼 養 頭 数 } \\
\hline \multirow[t]{2}{*}{ 実 数 } & 文平成 29 年 & 千頭 & $9,346.0$ & 630.9 & $1,528.0$ & 255.4 & $2,503.0$ & 648.2 & 55.8 & 266.4 & 293.8 & $2,948.0$ & 217.2 \\
\hline & 30 & $\prime \prime$ & $9,189.0$ & 625.7 & $1,519.0$ & 252.7 & $2,425.0$ & 649.3 & 50.2 & 280.6 & 293. 6 & $2,867.0$ & 225.8 \\
\hline 対前年比 & $30 / 29$ & $\%$ & 98.3 & 99.2 & 99.4 & 98.9 & 96.9 & 100.2 & 90.0 & 105.3 & 99.9 & 97.3 & 104.0 \\
\hline 全国割合 & 平成 29 年 & $"$ & 100.0 & 6.8 & 16.3 & 2.7 & 26.8 & 6.9 & 0.6 & 2.9 & 3.1 & 31.5 & 2.3 \\
\hline & 30 & $\prime \prime$ & 100.0 & 6.8 & 16.5 & 2. 8 & 26.4 & 7.1 & 0.5 & 3.1 & 3. 2 & 31.2 & 2. 5 \\
\hline
\end{tabular}


（3） 肥育豚の飼養頭数規模別飼養戸数・頭数

肥育豚の飼養頭数規模別（学校、試験場等の非営利的な飼養者を含まない。）にみると、飼養 戸数及び飼養頭数は、ともに前年に比べ 2,000 頭以上の階層で増加したが、これ以外の階層では 減少した。

なお、飼養頭数規模別の飼養頭数割合は、2,000頭以上の階層が約 7 割を占めている。

\section{図13＼cjkstart肥育豚の飼養頭数規模別飼養戸数・頭数の前年比較}

一飼養戸数一

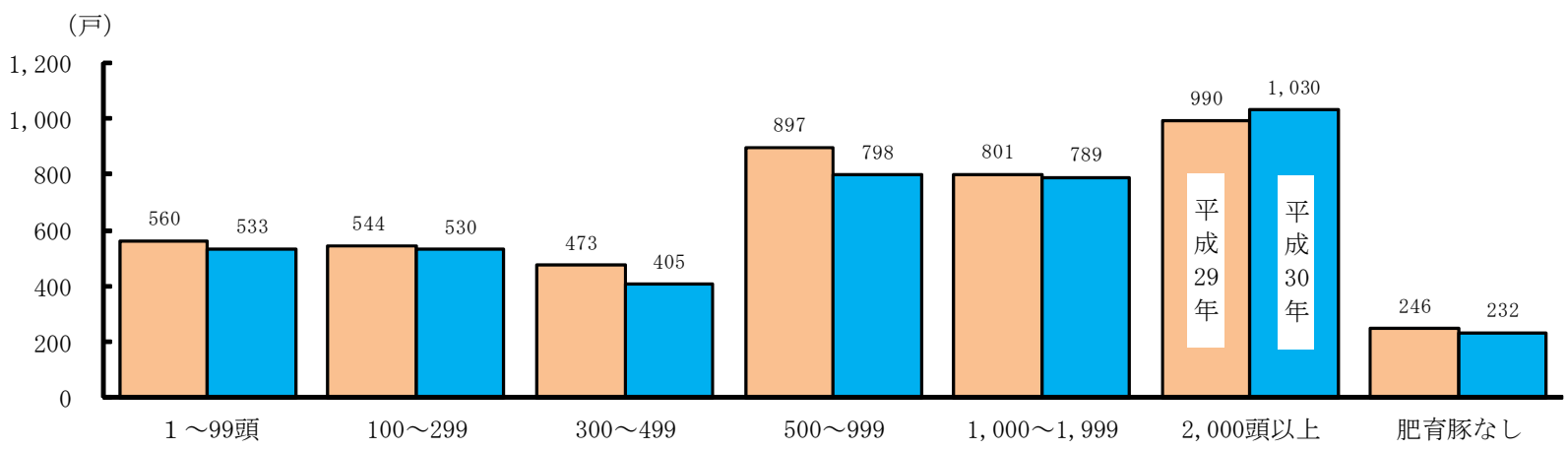

一飼養頭数一

(千頭)

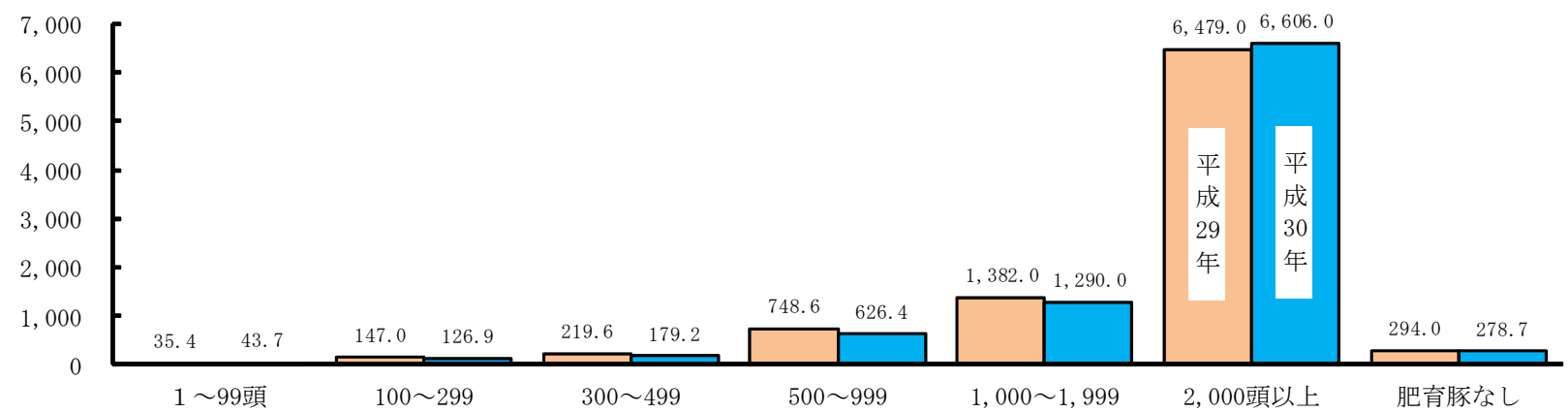

表16 肥育豚の飼養頭数規模別飼養戸数・頭数

\begin{tabular}{|c|c|c|c|c|c|c|c|c|c|c|c|}
\hline \multirow[b]{2}{*}{ 区 } & \multirow{2}{*}{$\begin{array}{l}\text { 単 } \\
\text { 位 }\end{array}$} & \multirow[b]{2}{*}{ 計 } & \multicolumn{2}{|c|}{ 肥 } & 豚 & 飼 & 頭 & 数 & 規 & & \multirow{2}{*}{$\begin{array}{l}\text { 肥育豚 } \\
\text { な し }\end{array}$} \\
\hline & & & 小 計 & 1 ～99頭 & $\begin{array}{r}100 \sim \\
299\end{array}$ & $\begin{array}{r}300 \sim \\
499\end{array}$ & $\begin{array}{l}500 \sim \\
999\end{array}$ & $\begin{array}{r}1,000 \sim \\
1,999\end{array}$ & $\begin{array}{c}2,000 \text { 頭 } \\
\text { 以上 }\end{array}$ & $\begin{array}{c}3,000 \text { 頭 } \\
\text { 以上 }\end{array}$ & \\
\hline \multicolumn{12}{|l|}{ 飼 養 戸 数 } \\
\hline 実 数 平成 29 年 & 戸 & 4,510 & 4,270 & 560 & 544 & 473 & 897 & 801 & 990 & 663 & 246 \\
\hline 30 & $\prime \prime$ & 4,310 & 4,080 & 533 & 530 & 405 & 798 & 789 & 1,030 & 667 & 232 \\
\hline 対前年比 $30 / 29$ & $\%$ & 95.6 & 95.6 & 95.2 & 97.4 & 85.6 & 89.0 & 98.5 & 104.0 & 100.6 & 94.3 \\
\hline 成 比 平成 29 年 & $"$ & 100.0 & 94.7 & 12.4 & 12.1 & 10.5 & 19.9 & 17.8 & 22.0 & 14.7 & 5.5 \\
\hline 30 & $" \prime$ & 100.0 & 94.7 & 12.4 & 12.3 & 9.4 & 18.5 & 18. 3 & 23. 9 & 15.5 & 5. 4 \\
\hline \multicolumn{12}{|l|}{ 飼 養 頭 数 } \\
\hline 数 平成 29 年 & 千頭 & $9,306.0$ & $9,012.0$ & 35.4 & 147.0 & 219.6 & 748.6 & $1,382.0$ & $6,479.0$ & $5,613.0$ & 294.0 \\
\hline 30 & $\prime \prime$ & $9,151.0$ & $8,872.0$ & 43.7 & 126.9 & 179. 2 & 626.4 & $1,290.0$ & $6,606.0$ & $5,684.0$ & 278.7 \\
\hline 対 前 年 比 & $\%$ & 98.3 & 98.4 & 123.4 & 86.3 & 81.6 & 83.7 & 93.3 & 102.0 & 101.3 & 94.8 \\
\hline 構 成 比平成 29 年 & $"$ & 100.0 & 96.8 & 0.4 & 1.6 & 2.4 & 8.0 & 14.9 & 69.6 & 60.3 & 3.2 \\
\hline 30 & $\prime \prime$ & 100.0 & 97.0 & 0.5 & 1.4 & 2.0 & 6.8 & 14. 1 & 72.2 & 62.1 & 3. 0 \\
\hline
\end{tabular}

注 : 1 この表には学校、試験場等の非営利的な飼養者は含まない。

2 この表の飼養頭数は、各階層の飼養者が飼っている全ての豚（子取り用めす豚、肥育豚、種お寸豚、その他（肥育用のもと豚等）を含 む。）の頭数である。 


\section{4 採卵鶏}

(1) 飼養戸数 $\cdot$ 羽数

平成30年の全国の採卵鶏の飼養戸数は2,200戸で、廃業等により前年に比べ150戸 $(6.4 \%)$ 減 少した。

採卵鶏（種鵎を除く。）の飼養羽数は 1 億 8,195 万羽で、前年に比べ 558 万 4,000 羽 $(3.2 \%)$ 増 加した。

このうち、成鶏めす（ 6 か月以上）の飼養羽数は 1 億 3,903 万 6,000 羽で、前年に比べ 293 万 5 , 000羽 (2.2\%) 増加した。

なお、1戸当たり成鶏め寸飼養羽数は 6 万 3,200 羽で、前年に比べ5, 300羽増加した。

\section{図14採卵鶏の飼養戸数・羽数の推移}
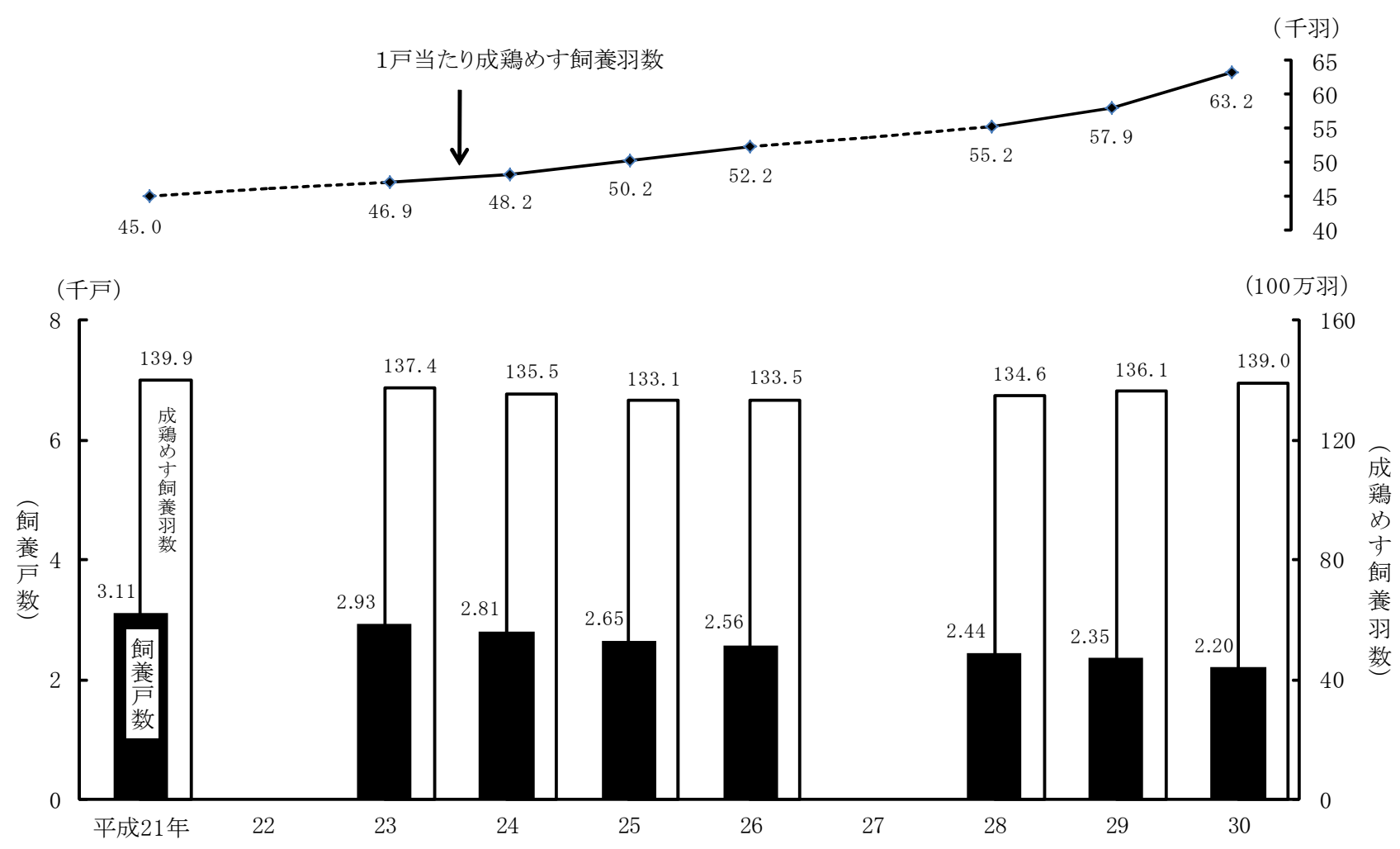

注 : 平成22年は2010年世界農林業センサス、平成 27 年は 2015 年農林業センサス実施年のため、調査を休止した。

表17 採卵鶏の飼養戸数 $\cdot$ 羽数

\begin{tabular}{|c|c|c|c|c|c|c|c|}
\hline \multirow[b]{2}{*}{ 区 } & \multirow[b]{2}{*}{ 分 } & \multirow[b]{2}{*}{$\begin{array}{l}\text { 採卵鶏の } \\
\text { 飼養戸数 }\end{array}$} & \multicolumn{4}{|c|}{$\begin{array}{llll}\text { 飼 } & \text { 養 } \text { 羽 数 } \\
\end{array}$} & \multirow{2}{*}{$\begin{array}{l}1 \text { 戸当たり } \\
\text { 成鶏めす } \\
\text { 飼養羽数 }\end{array}$} \\
\hline & & & 計 & $\begin{array}{c}\text { 採卵鶏 } \\
\text { (種鷄を除く。) }\end{array}$ & $\begin{array}{c}\text { 成鶏めす } \\
\text { (6か月以上) }\end{array}$ & 種鶏 & \\
\hline \multirow{4}{*}{ 実 } & 棹 & 戸 & 千羽 & 千羽 & 千羽 & 千. & 千羽 \\
\hline & 平成 28 年 & 2,440 & 175,733 & 173,349 & 134,569 & 2,38 & 55.2 \\
\hline & 29 & 2,350 & 178,900 & 176,366 & 136,101 & 2,53 & 57.9 \\
\hline & 30 & 2,200 & 184,350 & 181,950 & 139,036 & 2,400 & 63. 2 \\
\hline 対 前 年 比 & 比 $30 / 29(\%)$ & 93.6 & 103.0 & 103.2 & 102.2 & $94 . ?$ & - \\
\hline & 平成 28 年 $(\%)$ & - & 100.0 & 98.6 & 76.6 & 1.2 & - \\
\hline & 29 & - & 100.0 & 98.6 & 76.1 & 1.2 & - \\
\hline & 30 & - & 100.0 & 98.7 & 75.4 & 1.3 & - \\
\hline
\end{tabular}


（2）採卵鶏の全国農業地域別飼養戸数・羽数

全国農業地域別にみると、採卵鶏の飼養戸数は、全ての地域で減少した。

飼養羽数は、前年に比べ北海道、北陸及び近畿で減少したが、これ以外の地域では増加した。

なお、地域別の飼養羽数割合は、関東・東山が全国の約 3 割を占めている。

\section{図15＼cjkstart採卵鶏の全国農業地域別飼養戸数・羽数の前年比較}

一飼養戸数一

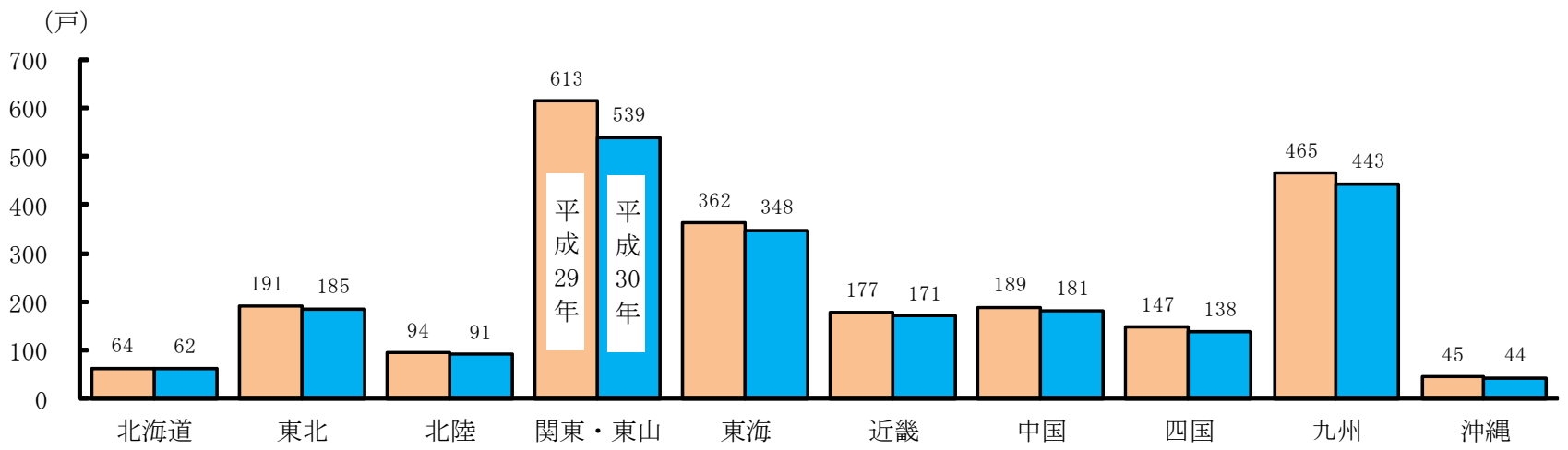

一飼養羽数一

(千羽)

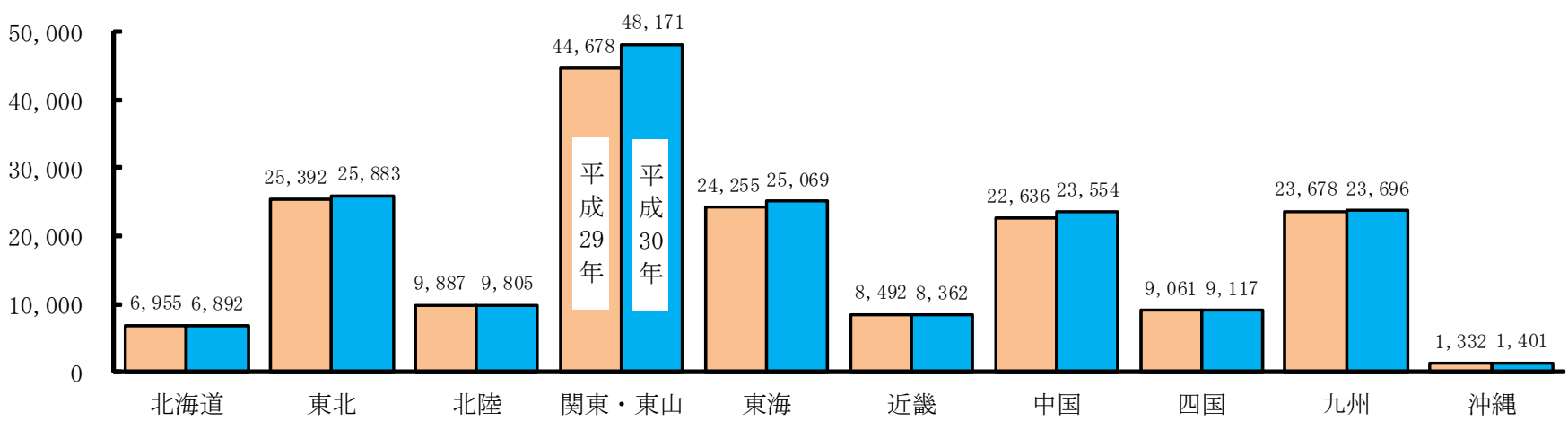

表18＼cjkstart採卵鶏の全国農業地域別飼養戸数・羽数

\begin{tabular}{|c|c|c|c|c|c|c|c|c|c|c|c|c|c|}
\hline 区 & 分 & 単位 & 全 国 & 北海 道 & 東 北 & 北 陸 & $\begin{array}{l}\text { 関 東 } \\
\text { 東 山 }\end{array}$ & 東 海 & 近 畿 & 中 国 & 四 国 & 九 州 & 沖 縄 \\
\hline \multicolumn{14}{|c|}{ 飼 養 戸 数 } \\
\hline & 女平成 29 年 & 戸 & 2,350 & 64 & 191 & 94 & 613 & 362 & 177 & 189 & 147 & 465 & 45 \\
\hline & 30 & $\prime \prime$ & 2,200 & 62 & 185 & 91 & 539 & 348 & 171 & 181 & 138 & 443 & 44 \\
\hline 対前年比 & t $30 / 29$ & $\%$ & 93.6 & 96.9 & 96.9 & 96.8 & 87.9 & 96.1 & 96.6 & 95.8 & 93.9 & 95.3 & 97.8 \\
\hline \multirow[t]{2}{*}{ 全国割合 } & 平成 29 年 & $"$ & 100.0 & 2.7 & 8.1 & 4. 0 & 26. 1 & 15.4 & 7. 5 & 8.0 & 6.3 & 19.8 & 1.9 \\
\hline & 30 & $\prime \prime$ & 100.0 & 2.8 & 8.4 & 4. 1 & 24.5 & 15. 8 & 7. 8 & 8. 2 & 6.3 & 20.1 & 2. 0 \\
\hline \multirow{3}{*}{$\begin{array}{c}\text { 飼 養羽 数 } \\
\text { 実 }\end{array}$} & & & & & & & & & & & & & \\
\hline & 平成 29 年 & 千羽 & 176,366 & 6,955 & 25,392 & 9,887 & 44,678 & 24,255 & 8,492 & 22,636 & 9,061 & 23,678 & 1,332 \\
\hline & 30 & $\prime \prime$ & 181,950 & 6,892 & 25,883 & 9,805 & 48,171 & 25,069 & 8,362 & 23,554 & 9,117 & 23,696 & 1,401 \\
\hline 対前年比 & $=\quad 30 / 29$ & $\%$ & 103.2 & 99.1 & 101.9 & 99.2 & 107.8 & 103. 4 & 98.5 & 104.1 & 100.6 & 100.1 & 105.2 \\
\hline \multirow[t]{2}{*}{ 全国割合 } & 平成 29 年 & $"$ & 100.0 & 3.9 & 14. 4 & 5.6 & 25.3 & 13. 8 & 4.8 & 12.8 & 5.1 & 13.4 & 0.8 \\
\hline & 30 & " & 100.0 & 3.8 & 14. 2 & 5.4 & 26.5 & 13. 8 & 4. 6 & 12. 9 & 5. 0 & 13.0 & 0.8 \\
\hline
\end{tabular}


（3）成鶏めす飼養羽数規模別飼養戸数・成鶏めす飼養羽数

成鶏めすの飼養羽数規模別（学校、試験場等の非営利的な飼養者を含まない。に）にみると、飼 養戸数は、前年に比べ全ての階層で減少した。

飼養羽数は、前年に比べ100, 000羽以上の階層で増加したが、これ以外の階層では減少した。

なお、飼養羽数規模別の飼養羽数割合は、100, 000羽以上の階層が約 8 割を占めている。

\section{図16＼cjkstart成鶏めすの飼養羽数規模別飼養戸数・成鶏めす飼養羽数の前年比較}

一飼養戸数一

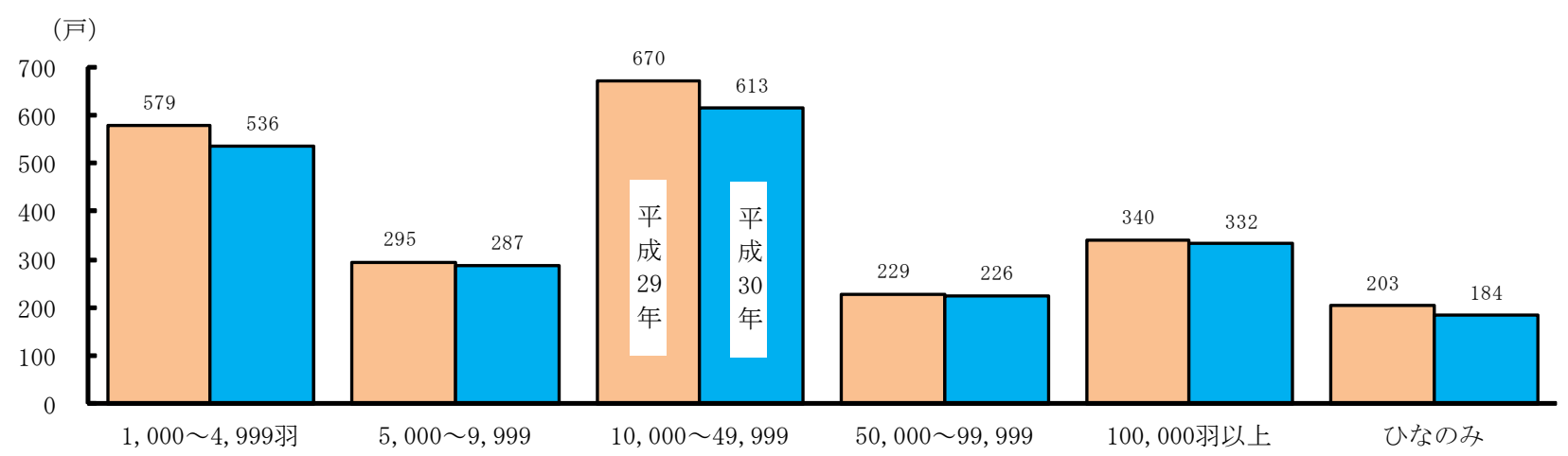

一成鷄めす飼養羽数一

(千羽)

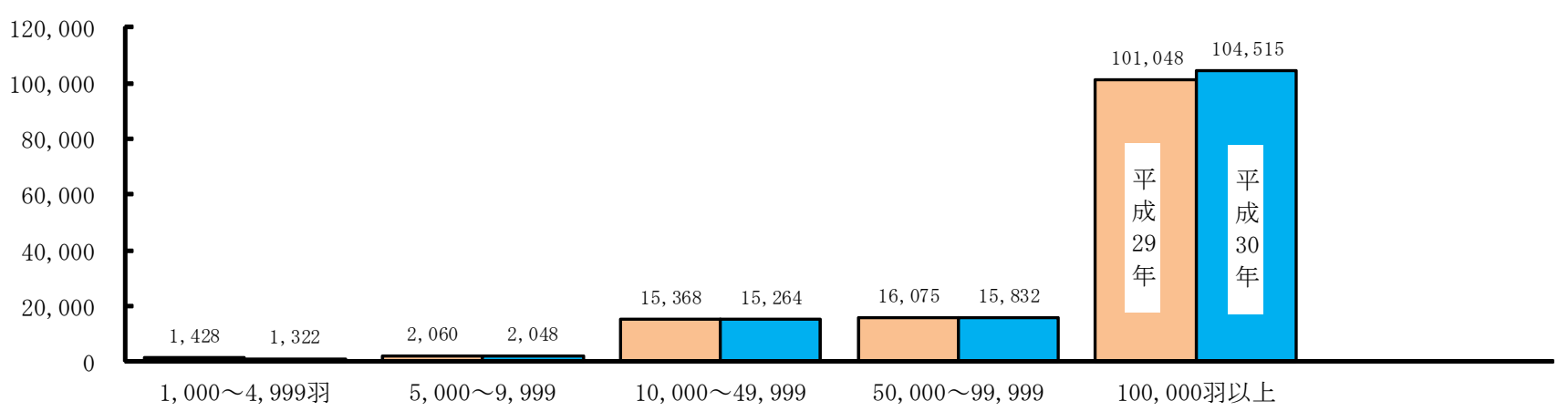

表19 成鶏めすの飼養羽数規模別飼養戸数 - 成鶏めす飼養羽数

\begin{tabular}{|c|c|c|c|c|c|c|c|c|c|}
\hline \multirow[b]{2}{*}{ 区 } & \multirow[b]{2}{*}{ 分 } & \multirow{2}{*}{$\begin{array}{l}\text { 単 } \\
\text { 位 }\end{array}$} & \multirow[b]{2}{*}{ 計 } & 成 & $\begin{array}{lll}\text { 鵎 } & \text { め } \\
\end{array}$ & 飼 & 羽 数 規 & "模 & \multirow[b]{2}{*}{ ひなのみ } \\
\hline & & & & $\begin{array}{l}\text { 1, 000〜 } \\
\text { 4,999羽 }\end{array}$ & $\begin{array}{r}5,000 \sim \\
9,999\end{array}$ & $\begin{array}{r}10,000 \sim \\
49,999\end{array}$ & $\begin{array}{r}50,000 \sim \\
99,999\end{array}$ & $\begin{array}{c}100,000 \text { 羽 } \\
\text { 以上 }\end{array}$ & \\
\hline \multicolumn{10}{|l|}{ 飼 養 戸 数 } \\
\hline \multirow[t]{2}{*}{ 実 } & 数 平成 29 年 & 戸 & 2,320 & 579 & 295 & 670 & 229 & 340 & 203 \\
\hline & 30 & $\prime \prime$ & 2,180 & 536 & 287 & 613 & 226 & 332 & 184 \\
\hline \multirow{3}{*}{$\begin{array}{l}\text { 対 前 年 } \\
\text { 構 成 }\end{array}$} & 比 $30 / 29$ & $\%$ & 94.0 & 92.6 & 97.3 & 91.5 & 98.7 & 97.6 & 90.6 \\
\hline & 比 平成29年 & $"$ & 100.0 & 25.0 & 12.7 & 28.9 & 9.9 & 14.7 & 8.8 \\
\hline & 30 & $\prime \prime$ & 100.0 & 24.6 & 13. 2 & 28.1 & 10.4 & 15.2 & 8. 4 \\
\hline \multicolumn{10}{|c|}{ 成鶏めす飼養羽数 } \\
\hline \multirow[t]{2}{*}{ 実 } & 数 平成 29 年 & 千羽 & 135,979 & 1,428 & 2,060 & 15,368 & 16,075 & 101,048 & - \\
\hline & 30 & $\prime \prime$ & 138,981 & 1,322 & 2,048 & 15,264 & 15,832 & 104,515 & - \\
\hline \multirow{3}{*}{$\begin{array}{l}\text { 対 前 年 上 } \\
\text { 構 成 } 上\end{array}$} & 比 $30 / 29$ & $\%$ & 102.2 & 92.6 & 99.4 & 99.3 & 98.5 & 103.4 & - \\
\hline & 比平成 29 年 & $"$ & 100.0 & 1.1 & 1.5 & 11.3 & 11.8 & 74.3 & - \\
\hline & 30 & $\prime \prime$ & 100.0 & 1. 0 & 1.5 & 11.0 & 11.4 & 75.2 & - \\
\hline
\end{tabular}

注：1 この表には学校、試験場等の非営利的な飼養者は含まない。

2 この表には種䳕のみの飼養者は含まない。 
5 ブロイラー

（1） 飼養戸数・羽数及び出荷戸数・羽数

平成30年の全国のブロイラーの飼養戸数は2, 260戸で、廃業等により前年に比べ50戸 $(2.2 \%)$ 減少した。

飼養羽数は 1 億 3,877 万 6000 羽で、前年に比べ 385 万 3,000 羽（2.9\%）増加した。

なお、 1 戸当たり飼養羽数は 6 万 1,400 羽で、前年に比べ 3,000 羽増加した。

また、出荷戸数は2,270戸で、廃業等により前年に比べ50戸 (2.2\%) 減少した。

出荷羽数は 6 億8,928万羽で、前年に比べ1, 156万7, 000羽 (1.7\%) 増加した。

なお、 1 戸当たり出荷羽数は 30 万 3,600 羽で、前年に比べ 1 万 1,500 羽増加した。

図17 ブロイラーの飼養戸数・羽数の推移
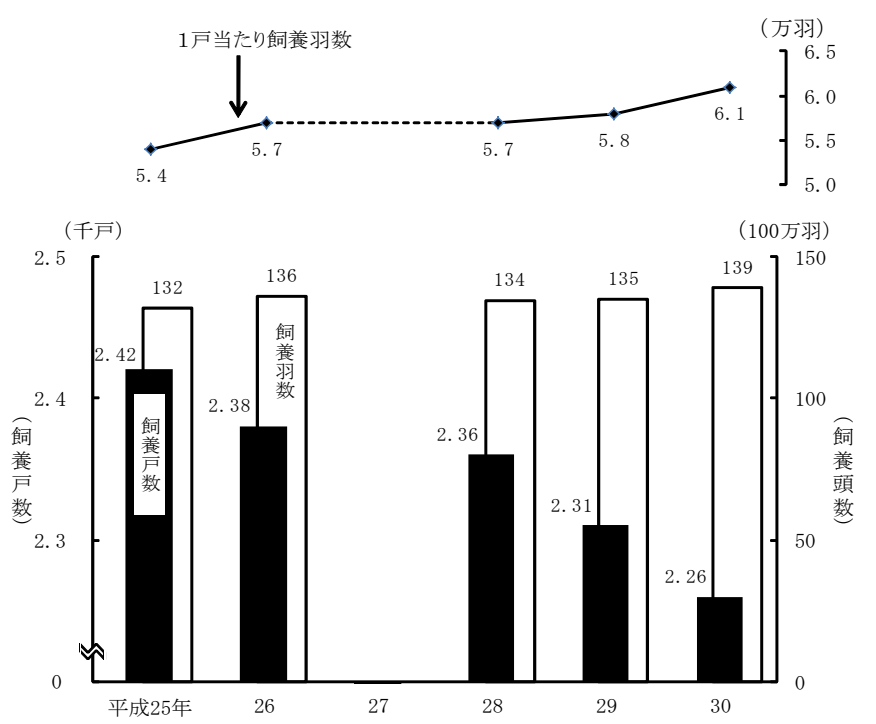

図18 ブロイラーの出荷戸数・羽数の推移

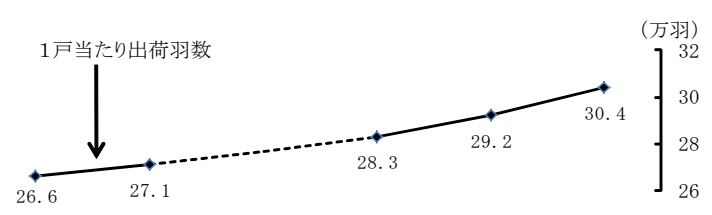

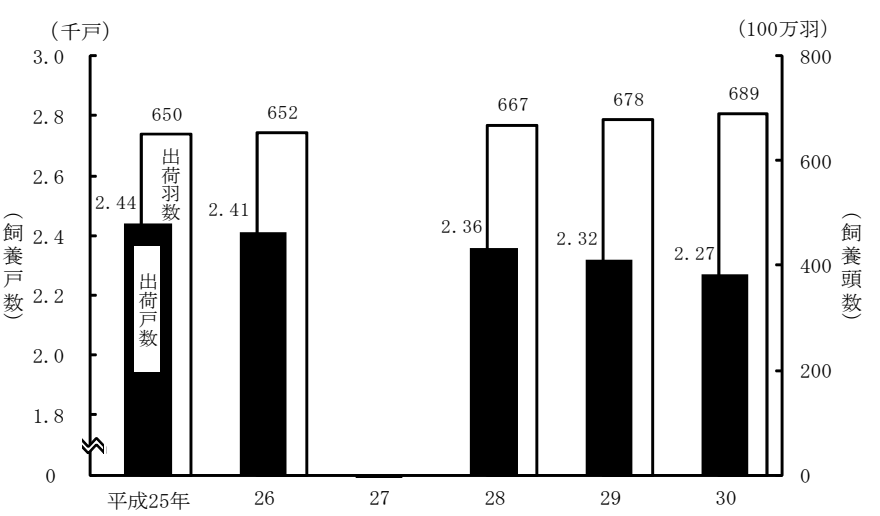

注 : 平成27年は2015年農林業センサス実施年のため、調査を休止した。

\section{表20 ブロイラーの飼養戸数 ·羽数及び出荷戸数 · 羽数}

\begin{tabular}{|c|c|c|c|c|c|c|c|}
\hline 区 & 分 & 飼養戸数 & 飼養羽数 & $\begin{array}{l}\text { 1戸当たり } \\
\text { 飼養羽数 }\end{array}$ & 出荷戸数 & 出荷羽数 & $\begin{array}{l}\text { 1戸当たり } \\
\text { 出荷羽数 }\end{array}$ \\
\hline \multirow[t]{3}{*}{ 実 } & & 戸 & 千羽 & 千羽 & 戸 & 千羽 & 千羽 \\
\hline & 平成28年 & 2,360 & 134,395 & 56.9 & 2,360 & 667,438 & 282.8 \\
\hline & 29 & 2,310 & 134,923 & 58.4 & 2,320 & 677,713 & 292.1 \\
\hline \multirow{2}{*}{ 対 前 年 比 } & 30 & 2,260 & 138,776 & 61.4 & 2,270 & 689,280 & 303.6 \\
\hline & $30 / 29(\%)$ & 97.8 & 102.9 & - & 97.8 & 101.7 & - \\
\hline
\end{tabular}

注：1 ブロイラーの飼養戸数・羽数及び出荷戸数・羽数には、ブロイラーの出荷羽数が年間 3,000 羽未満の飼養者を含まない。 22 月 1 日現在で飼養のない場合でも、過去 1 年間に 3,000 羽以上の出荷があれば出荷戸数に含めている。 
（2）ブロイラーの全国農業地域別出荷戸数・羽数

全国農業地域別にみると、ブロイラーの出荷戸数は、前年に比べ東海で増加し、北海道、中国 及び沖縄は前年並みとなり、これ以外の地域では減少した。

出荷羽数は、前年に比べ近畿及び四国で減少したが、これ以外の地域では増加した。

なお、地域別の出荷羽数割合は、九州が全国の約 5 割を占めている。

\section{図19ブロイラーの全国農業地域別出荷戸数・羽数の前年比較}

\section{一出荷戸数一}

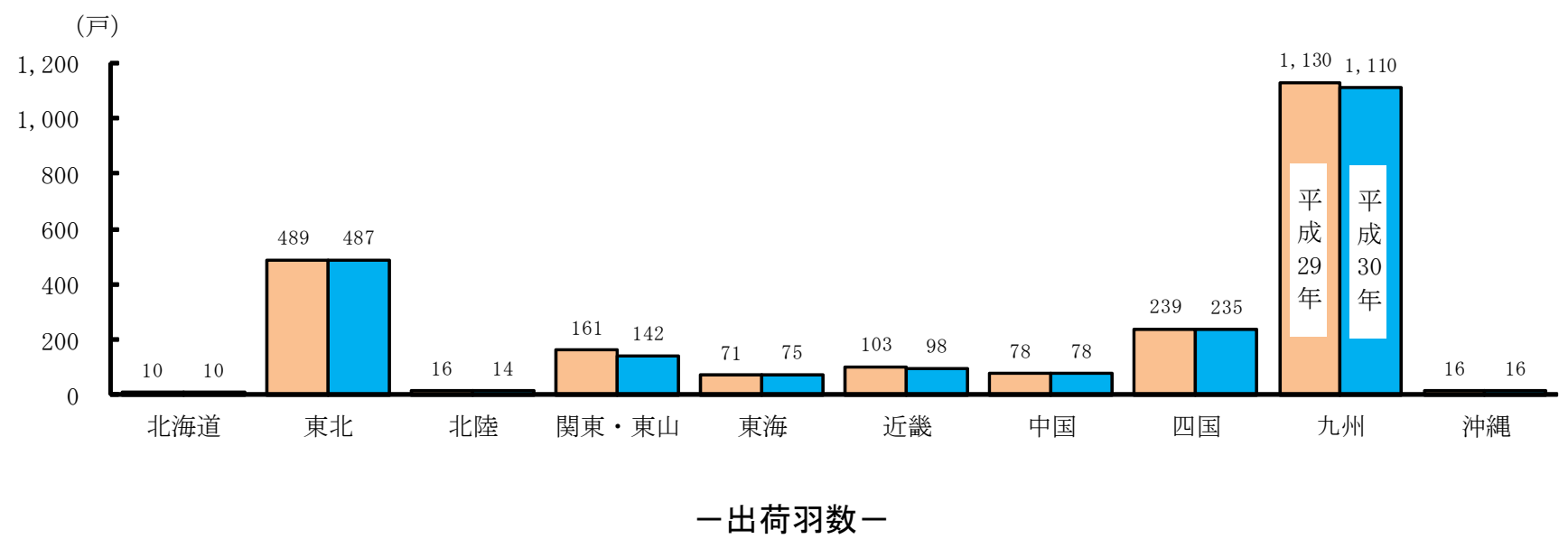

(千羽)

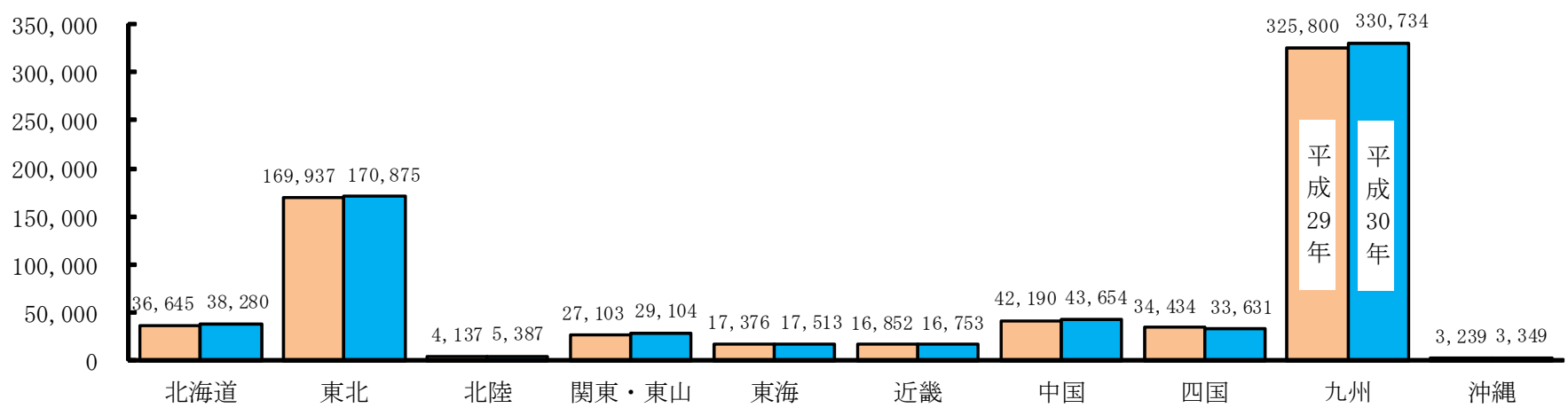

表21 ブロイラーの全国農業地域別出荷戸数 · 羽数

\begin{tabular}{|c|c|c|c|c|c|c|c|c|c|c|c|c|c|}
\hline 区 & 分 & 単位 & 全 国 & 北海道 & 東 北 & 北 陸 & $\begin{array}{l}\text { 関 東 } \\
\text { 東 山 }\end{array}$ & 東 海 & 近 畿 & 中 国 & 四 国 & 九 州 & 沖 縄 \\
\hline \multicolumn{14}{|c|}{ 出 荷 戸 数 } \\
\hline & 滧 平成 29 年 & 戸 & 2,320 & 10 & 489 & 16 & 161 & 71 & 103 & 78 & 239 & 1,130 & 16 \\
\hline & 30 & $\prime \prime$ & 2,270 & 10 & 487 & 14 & 142 & 75 & 98 & 78 & 235 & 1,110 & 16 \\
\hline \multirow{3}{*}{$\begin{array}{l}\text { 対前年比 } \\
\text { 全国割合 }\end{array}$} & $30 / 29$ & $\%$ & 97.8 & 100.0 & 99.6 & 87.5 & 88.2 & 105.6 & 95.1 & 100.0 & 98.3 & 98.2 & 100.0 \\
\hline & 平成 29 年 & $"$ & 100.0 & 0.4 & 21.1 & 0.7 & 6.9 & 3.1 & 4.4 & 3.4 & 10.3 & 48.7 & 0.7 \\
\hline & 30 & $\prime \prime$ & 100.0 & 0.4 & 21.5 & 0.6 & 6.3 & 3.3 & 4. 3 & 3.4 & 10.4 & 48. 9 & 0.7 \\
\hline \multicolumn{14}{|c|}{ 出 荷 羽 数 } \\
\hline \multirow[t]{2}{*}{ 実 数 } & 女平成 29 年 & 千羽 & 677,713 & 36,645 & 169,937 & 4,137 & 27,103 & 17,376 & 16,852 & 42,190 & 34,434 & 325,800 & 3,239 \\
\hline & 30 & $\prime \prime$ & 689,280 & 38,280 & 170,875 & 5,387 & 29,104 & 17,513 & 16,753 & 43,654 & 33,631 & 330,734 & 3,349 \\
\hline \multirow{3}{*}{$\begin{array}{l}\text { 対前年比 } \\
\text { 全国割合 }\end{array}$} & $=\quad 30 / 29$ & $\%$ & 101.7 & 104.5 & 100.6 & 130.2 & 107.4 & 100.8 & 99.4 & 103.5 & 97.7 & 101.5 & 103.4 \\
\hline & 平成 29 年 & $"$ & 100.0 & 5.4 & 25.1 & 0.6 & 4. 0 & 2.6 & 2.5 & 6.2 & 5.1 & 48.1 & 0.5 \\
\hline & 30 & $\prime \prime$ & 100.0 & 5. 6 & 24.8 & 0.8 & 4. 2 & 2. 5 & 2. 4 & 6.3 & 4. 9 & 48. 0 & 0.5 \\
\hline
\end{tabular}


（3）ブロイラーの出荷羽数規模別出荷戸数・羽数

ブロイラーの出荷羽数規模別（学校、試験場等の非営利的な飼養者を含まない。）にみると、 出荷戸数は、前年に比べ200, 000 羽以上の各階層で増加したが、これ以外の階層では減少した。 出荷羽数は、前年に比べ 300,000 羽以上の各階層で増加したが、これ以外の階層では減少した。 なお、出荷羽数規模別の出荷羽数割合は、 500,000 羽以上の階層が約 5 割を占めている。

\section{図20 ブロイラーの出荷羽数規模別出荷戸数・出荷羽数の前年比較}

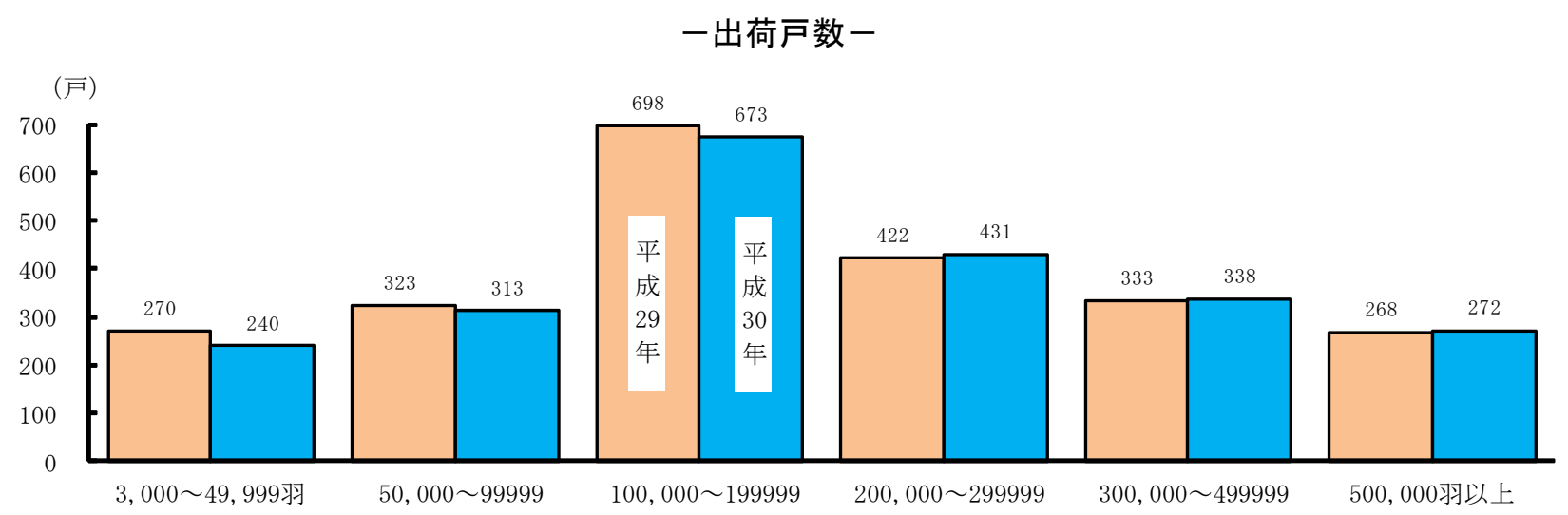

一出荷羽数一

(千羽)

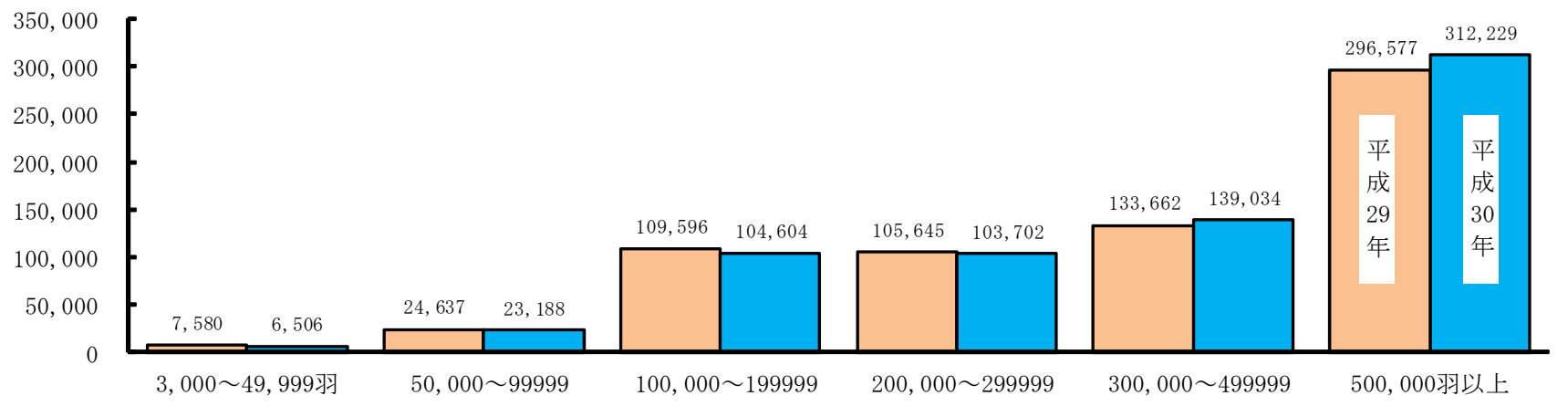

表22 ブロイラーの出荷羽数規模別出荷戸数・羽数

\begin{tabular}{|c|c|c|c|c|c|c|c|c|c|c|}
\hline 区 & & 分 & $\begin{array}{l}\text { 単 } \\
\text { 位 }\end{array}$ & 計 & $\begin{array}{l}3,000 \sim \\
49,999 \text { 羽 }\end{array}$ & $\begin{array}{r}50,000 \sim \\
99,999\end{array}$ & $\begin{array}{c}100,000 \sim \\
199,999\end{array}$ & $\begin{array}{c}200,000 \sim \\
299,999\end{array}$ & $\begin{array}{c}300,000 \sim \\
499,999\end{array}$ & $\begin{array}{c}500,000 \text { 羽 } \\
\text { 以上 }\end{array}$ \\
\hline \multicolumn{11}{|c|}{ 出 荷 戸 数 } \\
\hline \multirow[t]{2}{*}{ 実 } & 数 & 平成 29 年 & 戸 & 2,310 & 270 & 323 & 698 & 422 & 333 & 268 \\
\hline & & 30 & "I & 2,270 & 240 & 313 & 673 & 431 & 338 & 272 \\
\hline \multirow{3}{*}{$\begin{array}{l}\text { 対 前 年 } \\
\text { 構 成 }\end{array}$} & 比 & $30 / 29$ & $\%$ & 98.3 & 88.9 & 96.9 & 96.4 & 102.1 & 101.5 & 101.5 \\
\hline & 比 & 平成 29 年 & " & 100.0 & 11.7 & 14.0 & 30.2 & 18.3 & 14.4 & 11.6 \\
\hline & & 30 & $\prime \prime$ & 100.0 & 10.6 & 13.8 & 29.6 & 19.0 & 14.9 & 12. 0 \\
\hline \multicolumn{11}{|c|}{ 出 荷 羽 数 } \\
\hline \multirow[t]{2}{*}{ 実 } & 数 & 平成 29 年 & 千羽 & 677,697 & 7,580 & 24,637 & 109,596 & 105,645 & 133,662 & 296,577 \\
\hline & & 30 & $\prime \prime$ & 689,263 & 6,506 & 23,188 & 104,604 & 103,702 & 139,034 & 312,229 \\
\hline \multirow{3}{*}{$\begin{array}{l}\text { 対 前 年 } \\
\text { 構 成 }\end{array}$} & 比 & $30 / 29$ & $\%$ & 101.7 & 85.8 & 94.1 & 95.4 & 98.2 & 104.0 & 105. 3 \\
\hline & 比 & 平成 29 年 & " & 100.0 & 1. 1 & 3.6 & 16.2 & 15.6 & 19.7 & 43.8 \\
\hline & & 30 & $\prime \prime$ & 100.0 & 0.9 & 3. 4 & 15. 2 & 15. 0 & 20.2 & 45.3 \\
\hline
\end{tabular}

注 : この表には、学校, 試験場等の非営利的組織を含まない。 